\title{
Magmatic evolution biases basaltic records of mantle chemistry towards melts from recycled sources
}

\author{
David A. Neave ${ }^{\mathrm{a}, \mathrm{b}, *}$, Olivier Namur ${ }^{\mathrm{c}}$, Oliver Shorttle ${ }^{\mathrm{d}, \mathrm{e}}$, François Holtz $^{\mathrm{b}}$ \\ ${ }^{a}$ School of Earth and Environmental Sciences, The University of Manchester, Oxford Road, Manchester, \\ M13 9PL, United Kingdom \\ ${ }^{b}$ Leibniz Universität Hannover, Institut für Mineralogie, Callinstraße 3, 30167 Hannover, Germany \\ ${ }^{c}$ Department of Earth and Environmental Sciences, KU Leuven, Celestijnenlaan 200e, 3001 Leuven, \\ Belgium \\ ${ }^{d}$ Department of Earth Sciences, University of Cambridge, Downing Street, Cambridge, CB2 3EQ, United \\ Kingdom \\ ${ }^{e}$ Institute of Astronomy, University of Cambridge, Madingley Road, Cambridge, CB3 OHA, United \\ Kingdom
}

\begin{abstract}
The chemistry of erupted magmas provides a crucial window into the composition and structure of Earth's convecting mantle. However, magmatic evolution in the crust makes it challenging to reconstruct mantle properties from volcanic rocks in important but incompletely understood ways. Here we investigate how mantle-derived compositional variability in primary oceanic basalts determines their phase equilibria relations and the nature of the geochemical signals they record. By performing experiments on synthetic analogues of compositionally extreme primitive lavas from the Reykjanes Peninsula of Iceland at realistic magma storage conditions $\left(300 \mathrm{MPa}, 1140-1260{ }^{\circ} \mathrm{C}\right)$, we show that melts from enriched mantle domains retain higher melt fractions as they cool than those generated by melting of typical fertile lherzolite (i.e. they crystallise less mass over any interval of decreasing temperature). These melt fraction differences arise because plagioclase crystallisation is suppressed in $\mathrm{Na}$ - and $\mathrm{H}_{2} \mathrm{O}$-rich but $\mathrm{Ca}$ - and $\mathrm{Al}$-poor liquids derived from enriched source lithologies. Thus, compositional characteristics inherited from the mantle have a first-order control on the efficiency with which cooling basalts crystallise. This means that enriched melts will be more likely to survive crustal processing than depleted melts. Basalt chemistry will therefore be disproportionately influenced by melts from volumetrically minor enriched lithologies compared with melts from the upper mantle's most common lithology, lherzolite,
\end{abstract}


systematically biasing basaltic records towards melts from recycled mantle sources.

We combine our experimental observations from Iceland with thermodynamic simulations on mid-ocean ridge basalt compositions and show that mantle-derived variability in crystallisation efficiency can explain two enigmatic features of the global oceanic basalt record: firstly, the anomalous over-enrichment of incompatible elements during the differentiation of mid-ocean ridge basalts, which may reflect a progressive bias towards enriched compositions as differentiation proceeds; and secondly, the frequently documented cargoes of highly anorthitic plagioclase crystals carried by evolved and enriched liquids from which they cannot have crystallised. These crystals can now be understood as the solidified remnants of depleted, lherzolite-derived melts that have been entrained into melt mixtures from more enriched sources. Increases in the degree of enrichment of cumulate rocks sampled from progressively shallower horizons of the oceanic crust can also be interpreted in terms of enriched melts surviving crustal processing in preference to depleted melts.

Keywords: magmatic evolution, basalt phase equilibria, mantle heterogeneity, geochemical variability, Iceland, MORB

\section{Introduction}

Volcanism at mid-ocean ridges and ocean islands provides an avenue for investigating the 3 present-day diversity and spatial distribution of chemical heterogeneity in Earth's convecting 4 mantle (Schilling, 1973; Dupré and Allègre, 1983; Zindler and Hart, 1986), complementing 5 observations on mantle rocks that have been exhumed over longer timescales (e.g., Dick 6 et al., 1984; Johnson et al., 1990; Warren, 2016). A key realisation over past decades has 7 been that much of the mantle's geochemical variability can be linked to recycling, whereby 8 the subduction of oceanic lithosphere into the Earth's deep interior has produced chemically distinct reservoirs that have survived convective stirring over billion-year timescales (Chase, 1981; Hofmann and White, 1982; Hofmann, 1997; Stracke, 2012). This paradigm has been

\footnotetext{
*School of Earth and Environmental Sciences, The University of Manchester, Oxford Road, Manchester, M13 9PL, United Kingdom

Email address: david.neave@manchester.ac.uk (David A. Neave)

Preprint submitted to Earth and Planetary Science Letters

May 18, 2019
} 
established in part with observations on oceanic basalts from densely sampled regions such as Hawaii and Iceland where correlations between isotopic, trace-element and major-element markers of enrichment are thought to reflect the involvement of recycled and lithologically distinct mantle domains in melt generation (Hauri, 1996; Shorttle and Maclennan, 2011). Indeed, it has been shown that lithological variability in the mantle expands the diversity of possible primary melt compositions considerably (Hirschmann and Stolper, 1996; Kogiso et al., 1998; Shorttle et al., 2014; Jennings et al., 2016).

Despite the now abundant evidence for lithological heterogeneity in the mantle, deriving quantitative estimates of mantle source mineralogies from basalt records is a major challenge. One reason for this is the well-documented bias that enriched, recycled mantle sources with high clinopyroxene contents have lower solidus temperatures and higher fusibilities than fertile lherzolites (e.g., Hirschmann and Stolper, 1996; Phipps Morgan, 2001), which must be accounted for when estimating mass fractions of recycled material in basalt source regions (Shorttle et al., 2014; Brown and Lesher, 2014). Moreover, enriched sources, which are often but not exclusively associated with ocean island magmatism, are also more hydrous than their depleted equivalents, further enhancing their fusibility (Wallace, 1998; Asimow and Langmuir, 2003). However, the impacts of variable source composition and fusibility on the evolution and compositional systematics of oceanic basalts remain to be investigated. In particular, the effects of mantle-derived compositional variability and primary melt diversity on the crystallisation efficiency (i.e. mass of crystals produced for any given amount of cooling) and hence survivability of primitive basalts during transport to the surface are poorly understood. This is despite long-standing observations that almost all basalts have experienced some compositional modification en route to the surface and that truly primary magmas are exceedingly rare in the rock record (O'Hara, 1968). Characterising rates of mass loss from compositionally distinct basaltic melts undergoing cooling and crystallisation is thus critical if we are to relate chemical variability observed at the surface to chemical and lithological heterogeneities in the mantle.

Phase equilibria experiments performed on oceanic basalts have typically focussed on compositionally uniform model systems or somewhat evolved systems that represent the 
mixed derivatives of initially more diverse primary melts (e.g., Grove and Bryan, 1983; Elthon and Scarfe, 1984; Grove et al., 1992; Villiger et al., 2007; Feig et al., 2010). As a consequence, the different mass loss rates experienced by cooling primary melts with different compositions remains unquantified. A more detailed understanding of phase equilibria relations in mafic magmas is thus required. Here we use new experiments on synthetic analogues of compositionally extreme primitive basalts from Iceland's Reykjanes Peninsula to demonstrate how the evolution paths and crystallisation efficiencies of cooling magmas are controlled by the geochemical characteristics they inherit from the mantle. We then combine our observations on Icelandic systems with thermodynamic simulations to illustrate how records of mantle chemistry preserved in basalts from Iceland and mid-ocean ridges may be biased towards those carried by melts from recycled mantle sources.

\section{Starting compositions}

The abundance of primitive lavas on the Reykjanes Peninsula of Iceland makes it an excellent location for studying the generation and evolution of oceanic basalts (Jakobsson et al., 1978). In particular, the Háleyjabunga and Stapafell lavas comprise some of the most geochemically different basalts known from Iceland in terms of their isotopic and incompatible trace element (ITE) compositions, and have proven formative in understanding melting processes and the lengthscales of mantle heterogeneity (Fig. 1; Gurenko and Chaussidon, 1995; Maclennan, 2008b). Indeed, these lavas are thought to have been derived from lithologically distinct mantle domains, with the ITE-depleted Háleyjabunga lava resulting from high-degree melting of an initially fertile lherzolite and the ITE-enriched Stapafell lava resulting from modest-degree melting of a recycled and modally enriched (i.e. clinopyroxenerich) peridotite, sometimes referred to, sensu lato, as pyroxenite (Shorttle and Maclennan, 2011; Neave et al., 2018). Central to this interpretation is the recognition that the Fe- and Na-rich but Ca- and Al-poor Stapafell lava could not have been generated by melting a fertile lherzolite, while the Fe- and Na-poor but Ca- and Al-rich Háleyjabunga lava could (Shorttle and Maclennan, 2011). Háleyjabunga and Stapafell, which we shall consider as depleted and enriched end-members throughout, therefore represent ideal systems for isolat- 
ing and evaluating the effects of mantle-derived compositional variability on the evolution of primitive basalts.

Prior to synthesising starting materials based on lava compositions, the Stapafell matrix glass composition was corrected to a similar melt $\mathrm{MgO}$ content as the Háleyjabunga matrix glass composition (Condomines et al., 1983; Gurenko and Chaussidon, 1995; Peate et al., 2009). Although primary melt $\mathrm{MgO}$ contents can vary substantially with melting depth, melting degree and source composition (e.g., Kinzler and Grove, 1992; Hirose and Kushiro, 1993; Kogiso et al., 1998; Jennings et al., 2016), we sought to minimise initial MgO variability in our starting glasses in order to test whether melt $\mathrm{MgO}$ content is a robust index of magmatic differentiation. This is important because many models of basalt petrogenesis assume that melt $\mathrm{MgO}$ content and many other commonly used differentiation indices such as magnesium number $\left(\mathrm{Mg} \#\right.$, where $\mathrm{Mg} \#=$ molar $\left.\mathrm{Mg} /\left(\mathrm{Mg}+\mathrm{Fe}^{2+}\right)\right)$ are simply related to the fractions of melt remaining in evolving systems (e.g., O'Neill and Jenner, 2012; Coogan and O'Hara, 2015). Given that olivine dominates the mineral assemblage in both lavas (Neave et al., 2018), the correction was performed by adding equilibrium olivine to the mean Stapafell matrix glass composition with the Petrolog3 software package until a melt MgO content of $\sim 10.5$ wt.\% was achieved (Danyushevsky and Plechov, 2011; Herzberg and O'Hara, 2002). This resulted in Mg\# values of 0.73 and 0.67 for Háleyjabunga and Stapafell respectively when assuming a ferric-to-total iron $\left(\mathrm{Fe}^{3+} / \Sigma \mathrm{Fe}\right)$ ratio of $\sim 0.14$ (Shorttle et al., 2015). We also note that correcting matrix glasses to be in equilibrium with the most primitive olivines in each lava $\left(X_{\mathrm{Fo}}=91\right.$ and 88 for Háleyjabunga and Stapafell respectively, where $X_{\mathrm{Fo}}=$ molar $\left.\mathrm{Mg} /(\mathrm{Mg}+\mathrm{Fe})\right)$ would simply lengthen the interval of olivine-only crystallisation experienced by the depleted Háleyjabunga composition with respect to that experienced by the enriched Stapafell composition (Fig. A.1; Neave et al., 2018). This would have only second-order effects on the results and interpretations presented below. 


\section{Methods}

\subsection{Experimental methods}

Experimental starting materials were synthesised from reagent-grade oxide and carbonate powders that were mixed in acetone, dried and then ground in an agate mortar to ensure compositional homogeneity. Ground powders were subsequently melted twice in large-volume Pt crucibles at the Institut für Mineralogie of the Leibniz Universität Hannover, Germany. Each one-hour melting run was performed in air at $1600{ }^{\circ} \mathrm{C}$. Fused powders were quenched after each run by pouring them onto a clean brass plate and then placing crucibles containing any remaining melt into a bath of $\mathrm{H}_{2} \mathrm{O}$. After being checked for signs of quench crystallisation, glassy starting materials were powdered in an agate disc mill.

Crystallisation experiments were then performed in an internally heated pressure vessel at the Institut für Mineralogie of the Leibniz Universität Hannover, Germany. Two suites of equilibrium crystallisation experiments were carried out in graphite-Pt double capsules and Fe-presaturated $\mathrm{Au}_{80} \mathrm{Pd}_{20}$ capsules to investigate crystallisation under nominally dry (initial $\mathrm{H}_{2} \mathrm{O} \sim 0.1$ wt.\%) and low- $\mathrm{H}_{2} \mathrm{O}$ (initial $\mathrm{H}_{2} \mathrm{O} \sim 0.4$ wt.\%) conditions respectively (e.g., Husen et al., 2016). These $\mathrm{H}_{2} \mathrm{O}$ contents were selected to be as close as experimentally feasible to those expected in the Háleyjabunga and Stapafell melts, 0.03-0.04 and 0.4-0.5 wt.\% respectively based on reported Ce contents and nominal $\mathrm{H}_{2} \mathrm{O} / \mathrm{Ce}$ values of 180-250 (Gurenko and Chaussidon, 1995; Peate et al., 2009; Hartley et al., 2015; Bali et al., 2018). Oxygen fugacity $\left(f_{\mathrm{O}_{2}}\right)$ conditions were expected to be close to the carbon-carbon dioxide (CCO) redox buffer for the nominally dry experiments and approximately one log unit above the quartz-fayalite-magnetite (QFM) buffer for the low- $\mathrm{H}_{2} \mathrm{O}$ experiments (e.g., Husen et al., 2016). Although our approach conflates $f_{\mathrm{O}_{2}}$ with melt $\mathrm{H}_{2} \mathrm{O}$ content, the effects of variable $\mathrm{H}_{2} \mathrm{O}$ on mineral-liquid equilibria are expected to overshadow those of variable $f_{\mathrm{O}_{2}}$ within the oxide-free region of phase space examined here (Feig et al., 2010). Further experiments were carried out using starting materials synthesised using glass compositions produced during low- $\mathrm{H}_{2} \mathrm{O}$ experiments at $1200{ }^{\circ} \mathrm{C}$ in order to mimic fractional crystallisation (e.g., Villiger et al., 2007). 
Experiments were performed at $300 \mathrm{MPa}$ and $1140-1260{ }^{\circ} \mathrm{C}$ to reproduce the dominant conditions of magmatic differentiation beneath Icelandic rift zones (Neave and Putirka, 2017). These conditions also approach those experienced during mid ocean ridge basalt (MORB) petrogenesis (e.g., Grove et al., 1992), and offer vital insights into wider basalt phase equilibria relations at little-explored crustal pressure $(P)$ conditions. Importantly, experiments on both Háleyjabunga and Stapafell starting glasses were performed simultaneously to ensure that differences in experimental run products at any given set conditions reflect compositional effects alone. Further details about experimental methods and $f_{\mathrm{O}_{2}}$ conditions are provided in Appendix A.

\subsection{Analytical methods}

Experimental products (including capsules) were mounted in epoxy resin, polished and carbon coated for measurement by electron probe microanalysis (EPMA) with a Cameca SX100 instrument at the Institut für Mineralogie of the Leibniz Universität Hannover, Germany. To ensure internal consistency across multiple sessions, analyses were normalised to repeat measurements of appropriate Smithsonian Microbeam Standards (Jarosewich et al., 1980). Accuracy and precision were monitored by measuring additional Smithsonian Microbeam Standards (Jarosewich et al., 1980, 1987). Major (>1 wt.\%) and minor (<1 wt.\%) elements were determined with accuracies better than $2 \%$ and $10 \%$, and $1 \sigma$ precisions better than $1 \%$ and $15 \%$ respectively. In addition, the $\mathrm{H}_{2} \mathrm{O}$ content of superliquidus glasses was determined by Fourier-transform infrared (FTIR) spectroscopy with a Bruker IFS88 instrument, also at the Institut für Mineralogie of the Leibniz Universität Hannover, Germany. Typical analyses of standards are provided alongside analyses of experimental products in the Supplementary Material and more information about analytical methods is provided in Appendix A.

\section{Equilibrium phase relations}

The experimental phase relations we observe depend on the major-element chemistry of the starting materials and the melt $\mathrm{H}_{2} \mathrm{O}$ contents that evolve during the experiments 
(Figs. 2 and 3). Experiments on the depleted Háleyjabunga analogue are characterised by the following order of crystallisation: olivine \pm Cr-spinel, olivine + plagioclase, olivine + plagioclase + clinopyroxene (Figs. 2a, 3a, 3c and 3e). Low-Ca pyroxene then joins the crystallising assemblage in low- $\mathrm{H}_{2} \mathrm{O}$ experiments. In contrast, experiments on the enriched Stapafell analogue are characterised by the appearance of clinopyroxene before plagioclase, resulting in a different order of crystallisation: olivine \pm Cr-spinel, olivine + clinopyroxene, olivine + clinopyroxene + plagioclase (Figs. 2b, 3b, 3d and 3f). Again, low-Ca pyroxene then joins the crystallising assemblage in low- $\mathrm{H}_{2} \mathrm{O}$ experiments. The difference in major element chemistry between our two starting compositions thus translates to a difference in plagioclase liquidus temperature $(T)$ of $>40{ }^{\circ} \mathrm{C}$ in the presence of $\sim 0.5$ wt. $\% \mathrm{H}_{2} \mathrm{O}$ and $>20$ ${ }^{\circ} \mathrm{C}$ under nominally dry conditions. Experiments on simple systems provide a first-order explanation for these differences in plagioclase stability. Refractory melts rich in Ca and Al (like our depleted Háleyjabunga analogue) lie closer to low-variance cotectics bordering the plagioclase primary phase field than melts rich in $\mathrm{Na}$ and $\mathrm{Fe}$ (like our enriched Stapafell analogue) because of their higher normative anorthite contents (e.g., Presnall et al., 1978). Refractory melts therefore reach multiple saturation at relatively higher temperatures than enriched melts (Supplementary Fig. A.2). Although the products of our nominally dry experiments show similar orders of phase appearance to those of our low- $\mathrm{H}_{2} \mathrm{O}$ experiments, olivine and plagioclase liquidi are suppressed by $20-40{ }^{\circ} \mathrm{C}$ in the presence of $\sim 0.5 \mathrm{wt} . \% \mathrm{H}_{2} \mathrm{O}$, in line with previous observations (e.g., Almeev et al., 2007, 2012; Médard and Grove, 2008); within the thermal resolution of our experimental approach $\left(20^{\circ} \mathrm{C}\right)$, clinopyroxene stability appears to be unaffected by small amounts of $\mathrm{H}_{2} \mathrm{O}$ (Fig. 3). Cr-spinel and low-Ca pyroxene only occur in the highest- and lowest- $T$ experiments performed under low- $\mathrm{H}_{2} \mathrm{O}$ conditions respectively.

Differences in cumulative crystal assemblages between the products of equilibrium and near-fractional crystallisation experiments are modest until high degrees of crystallisation are attained (Figs. 3a-3d). For example, summing the crystal fractions produced at 1200 and $1180{ }^{\circ} \mathrm{C}$ in our near-fractional crystallisation experiments results in an assemblage similar to that generated at $1180{ }^{\circ} \mathrm{C}$ in our equilibrium experiments. Crystal assemblages only 
diverge significantly in the case of the low- $\mathrm{H}_{2} \mathrm{O}$ experiment on the depleted Háleyjabunga analogue at $1140{ }^{\circ} \mathrm{C}$, in which significant amounts of low-Ca pyroxene were produced at the expense of olivine via the forsterite $+\mathrm{SiO}_{2} \rightleftharpoons$ enstatite peritectic reaction in the case of the equilibrium crystallisation experiment (Fig. 3a). Our equilibrium and near-fractional crystallisation experiments nonetheless capture the same first-order phase relations, meaning that equilibrium experiments can be used to inform our understanding of natural systems evolving by primarily fractional processes (e.g., Melekhova et al., 2013).

\section{Melt compositions and melt fraction evolution trends}

Residual melts produced during the crystallisation of the depleted Háleyjabunga analogue evolve along compositional trajectories distinct from those produced during the crystallisation of the enriched Stapafell analogue (Fig. 4; Supplementary Figs. A.3 and A.4). For example, the depleted Háleyjabunga analogue preserves a relative enrichment in $\mathrm{Al}$ until both of the compositional systems investigated are saturated in olivine, plagioclase and clinopyroxene (Figs. 4a and 4c). It also maintains higher $\mathrm{Ca} / \mathrm{Na}$ values (expressed throughout as molar ratios) across the whole $T$ range explored (Figs. $4 \mathrm{~b}$ and $4 \mathrm{~d}$ ), though the higher$T$ saturation of plagioclase in depleted systems drives some convergence in major-element characteristics.

The products of experiments on the depleted Háleyjabunga analogue contain consistently less melt (i.e. quenched glass) at any given $\mathrm{T}$ or melt $\mathrm{MgO}$ content than those from experiments on the enriched Stapafell analogue, even though both starting compositions have similar liquidus (i.e. olivine saturation) temperatures at any given melt $\mathrm{H}_{2} \mathrm{O}$ content (Figs. 3 and 5). For example, melt makes up only $\sim 20 \mathrm{wt} . \%$ of the products of the experiment using the depleted starting composition under low- $\mathrm{H}_{2} \mathrm{O}$ conditions at $1140{ }^{\circ} \mathrm{C}$ (i.e. melt fraction $(F) \sim 0.2$, while it constitutes $\sim 50$ wt.\% of the products of the experiment using the enriched starting composition $(F \sim 0.5)$. A similar relationship observed in the products of nominally dry experiments is simply offset to higher temperatures: at $1140{ }^{\circ} \mathrm{C}$, the products of experiments on the depleted Háleyjabunga analogue contain only trace melt $(F \sim 0)$, whereas the products of experiments on the enriched Stapafell analogue still contain an ap- 
preciable $\sim 20$ wt.\% melt $(F \sim 0.2)$. Despite being unable to reproduce our experimentally derived $\mathrm{MgO}-F$ trends in detail, thermodynamic simulations with the MELTS algorithm (performed using the alphaMELTS frontend) nonetheless highlight the important control that primary melt compositions exert on the efficiency with which magmas crystallise as they cool (Fig. 5; Ghiorso and Sack, 1995; Smith and Asimow, 2005). Such calculations also reveal that depleted melts release considerably more heat per unit mass of initially supplied melt (expressed here as the cumulative enthalpy of fusion; $\Sigma\left[\Delta \mathrm{H}_{\text {fus }}\right](\mathrm{J} / \mathrm{g})$ ) during their early differentiation $\left(\mathrm{MgO}>7.5\right.$ wt.\%; $\left.T>1200{ }^{\circ} \mathrm{C}\right)$ than enriched melts, largely because of the considerable latent heat release associated with early plagioclase saturation (Fig. 6; Ghiorso, 1997; Namur et al., 2014; Shorttle et al., 2016). Thus, the latent heat released by the crystallisation of depleted melts may potentially thermally buffer and hence prevent the crystallisation of spatially associated enriched melts within long-lived mush columns or magma plumbing systems.

\section{The geochemical consequences of variable crystallisation efficiency}

In the previous two sections we have demonstrated that the efficiency with which cooling basalts crystallise is determined by their major element and $\mathrm{H}_{2} \mathrm{O}$ contents, independently or in concert (Fig. 5). However, observations on natural oceanic basalts indicate that variability in major elements and $\mathrm{H}_{2} \mathrm{O}$ is likely to be correlated (e.g., Michael and Chase, 1987; Michael, 1995). Indeed, particularly close relationships between $\mathrm{H}_{2} \mathrm{O}$ contents, ITE enrichment and major element compositions have been identified in Icelandic basalts (Shorttle and Maclennan, 2011; Hartley et al., 2015): ITE-depleted systems like Háleyjabunga are not only poor in $\mathrm{Na}$ and $\mathrm{Fe}$ but they are also poor in $\mathrm{H}_{2} \mathrm{O}$, whereas $\mathrm{Na}$-, Fe- and ITE-rich systems like Stapafell are correspondingly rich in $\mathrm{H}_{2} \mathrm{O}$. Therefore, in the following discussions we compare nominally dry experiments on the depleted Háleyjabunga analogue with low- $\mathrm{H}_{2} \mathrm{O}$ experiments on the enriched Stapafell analogue - these suites of experiments best represent the poles of geochemical variability present in southwest Iceland. 


\subsection{Incompatible trace element systematics in basalts}

In their study of MORB compositional systematics, O'Neill and Jenner (2012) argued that the ITE content of glasses related by fractional crystallisation should lie along straight lines in $\mathrm{MgO}-\log _{10}$ (ITE) space because of the form of the Rayleigh equation,

$$
\log _{10}\left([\mathrm{ITE}] /[\mathrm{ITE}]_{\mathrm{i}}\right)=\left(D_{\mathrm{ITE}}-1\right) \log _{10}(F),
$$

where $[\mathrm{ITE}]_{\mathrm{i}}$ is the initial ITE content and $D_{\mathrm{ITE}}$ is a bulk solid-liquid partition coefficient, and the apparent linear dependence of $\log _{10}(F)$ on melt $\mathrm{MgO}$ content (in wt.\%) in MORB systems,

$$
\log _{10}(F)=1.245+10.132[\mathrm{MgO}] .
$$

ITE evolution trajectories calculated for our Icelandic end-members using the approach and partition coefficients of O'Neill and Jenner (2012) and published ITE contents define parallel linear trends separated by the degree of ITE enrichment inherited from the mantle (Fig. 7; Condomines et al., 1983; Gurenko and Chaussidon, 1995; Peate et al., 2009). These trends account for little of the variability present in natural data. However, our experimental findings show that $\mathrm{MgO}-F$, and hence $\mathrm{MgO}-\log _{10}$ (ITE), relationships must be evaluated individually for different primary melt compositions; melt $\mathrm{MgO}$ content is not a unique index of magmatic differentiation. Specifically, the products of low- $\mathrm{H}_{2} \mathrm{O}$ experiments on the enriched Stapafell analogue retain high melt fractions $(F \sim 0.5)$ to low melt $\mathrm{MgO}$ contents $(\sim 6$ wt.\%), while only trace amounts of melt $(F \sim 0)$ remain at comparable melt $\mathrm{MgO}$ contents in the products of nominally dry experiments on the depleted Háleyjabunga analogue (Figs. 5a and 5b). We thus produced independent parametrisations of F's dependence on melt $\mathrm{MgO}$ content for our two end-member systems in order to quantify the effects of primary geochemical variability on the evolution of basalt ITE contents. In contrast with O'Neill and Jenner (2012), we fitted our experimental data with error functions because they capture the $F=1$ asymptotes at high melt $\mathrm{MgO}$ contents and the transitions to high crystallisation efficiencies after plagioclase saturation better than simple log-linear relationships (Supplementary Fig. A.5). 
ITE evolution paths calculated using our variable $\mathrm{MgO}-F$ relationships differ from those predicted with the $\mathrm{MgO}-F$ relationship of O'Neill and Jenner (2012) (Equation 2) in three important ways (Fig 7a): firstly, the rates at which ITEs become enriched (i.e. distilled and concentrated) by fractional crystallisation differ greatly between the two end-member systems; secondly, fractional crystallisation of the depleted Háleyjabunga analogue results in a higher rate of ITE enrichment for any given drop in melt $\mathrm{MgO}$ content than predicted by O’Neill and Jenner (2012), especially once melt MgO contents decrease below 8 wt.\%; and thirdly, fractional crystallisation of the enriched Stapafell analogue results in a lower rate of ITE enrichment than predicted by O'Neill and Jenner (2012). Differences in crystallisation efficiency are thus potentially capable of exerting a considerable influence over the compositional systematics of natural basalts. For example, the apparent lack of progressive ITE enrichment during the differentiation of enriched magmas may reflect the fact that they retain high melt fractions $(F>0.8)$ to well below 8 wt.\% MgO meaning that ITE concentrations will increase only modestly during early stages of differentiation.

Low-MgO magmas from southwest Iceland are enriched in ITEs with respect to most spatially associated high-MgO magmas (Fig. 7a). This absence of low-MgO, low-ITE compositions could be interpreted as evidence for the ITE content of residual depleted melts being driven up to levels comparable with those present in enriched melts by efficient crystallisation. However, if such residua existed in the erupted record, they would be readily identified from their ITE ratios or isotopic compositions (Fig. 7b; Shorttle et al., 2014). Indeed, magma mixing has been frequently invoked as a mechanism for erasing such signals of ITE depletion from evolving liquids (Maclennan, 2008a; Shorttle et al., 2016). Namely, progressive decreases in the ITE variability of olivine-hosted melt inclusion populations as a function of decreasing host $X_{\mathrm{Fo}}$ have been taken as evidence for concurrent mixing and crystallisation of initially variable melts (Maclennan, 2008a; Neave et al., 2013). Comparable observations have also been made on glass and whole-rock data, in which the most significant decrease in ITE variability occurs between $\sim 9.5$ and $\sim 8.0$ wt.\% MgO (Shorttle et al., 2014), with this window being potentially wider still in MORB systems (Shorttle, 2015). This window of melt $\mathrm{MgO}$ contents coincides with the interval over which differences 
between $\mathrm{MgO}-F$ relationships develop in our experimental dataset (Figs. 5 and 6). It is thus feasible that primitive melts remain unmixed over sufficiently long intervals of cooling that variations in crystallisation efficiency can influence their ITE systematics as discussed below (Figs. 7 and 8).

\subsection{Crystal cargoes}

The crystal cargoes of some Icelandic basalts demonstrate that primitive melts can undergo significant crystallisation before mantle-derived compositional variability is erased by mixing. For example, high-Mg\# clinopyroxene crystals from the Borgarhraun lava in north Iceland record crystallisation from systematically more depleted melts than coerupted olivine-hosted melt inclusions (Winpenny and Maclennan, 2011). High-anorthite $\left(X_{\mathrm{An}}\right.$, where $X_{\mathrm{An}}=$ molar $\left.\mathrm{Ca} /(\mathrm{Ca}+\mathrm{Na}+\mathrm{K})\right)$ plagioclase crystals from numerous lavas and tephras in Iceland's Eastern Volcanic Zone preserve comparable signals of crystallisation from liquids more depleted than those which carried them to the surface (Halldórsson et al., 2008; Neave et al., 2014, 2015). When combined with the recognition that depleted primitive lavas can avoid interactions with other melts during ascent (Hartley and Maclennan, 2018; Maclennan, 2019), these observations on crystals indicate that end-member primitive melts probably undergo sufficient isolated differentiation for variations in crystallisation behaviour to affect the compositional systematics of their differentiates. However, unambiguously separating the effects of mixing from the effects of phase equilibria variability is challenging because they produce similar elemental signals in the rock record. Tracking the isotopic evolution of seemingly cogenetic melts and melt inclusions in detail will be needed to provide clarity here (cf. Shorttle et al., 2014; Shorttle, 2015).

\subsection{Geochemical stratification of the crust}

The high crystallisation efficiency of depleted basalts does not only result in high ITE contents at low melt $\mathrm{MgO}$ contents (Fig. 7a). It also means that depleted basalts approach their solidi at temperatures where other basalts maintain appreciable melt fractions (Figs. 5c and 5d). Although our experimental approach overlooks important dynamical considerations 
like melt segregation (e.g., Wager et al., 1960), it suggests that depleted evolved melts which escape mixing would become volumetrically diminished to the point that they would either freeze in the crust or leave almost no geochemical trace when mixed into other magmas. In contrast, their enriched counterparts will persist. In other words, for any given thermal structure imposed by conductive and hydrothermal cooling of the crust, enriched melts in thermal equilibrium with their surroundings will penetrate in greater volumes to shallower depths than depleted melts. The mantle-derived geochemical properties of Icelandic basalts thus exert fundamental controls on their abilities to survive crustal processing and make it to the surface where they can be sampled.

\section{Biasing basalt compositions towards melts from enriched sources}

Much of the variability in primitive basalts supplied to the base of Icelandic crust can be described in terms of mixing between hypothetical depleted and enriched end-members, broadly comparable with the Háleyjabunga and Stapafell lavas respectively (Maclennan, 2008a,b). Given that these end-members represent melts from distinct mantle sources (Shorttle and Maclennan, 2011; Neave et al., 2018), basaltic liquids can thus be expressed in terms of the fraction of their mass derived from enriched sources $\left(X_{\mathrm{e}}\right)$ whereby $X_{\mathrm{e}}=0$ corresponds to the depleted Háleyjabunga end-member and $X_{\mathrm{e}}=1$ to the enriched Stapafell end-member. However, our experimental findings suggest that the apparent $X_{\mathrm{e}}$ of a suite of variably evolved basalts will not just be sensitive to the mean $X_{\mathrm{e}}$ originating in the mantle, but also the variable survivability of chemically distinct primitive melts. Specifically, for any initial combination of primitive enriched and depleted end-member melts entering a magmatic plumbing system $\left(\left[X_{\mathrm{e}}\right]_{\mathrm{i}}\right)$ and differentiating in isolation of each other, the mean value of $X_{\mathrm{e}}$ in the system increases with decreasing melt $\mathrm{MgO}$ content and $T$ (Figs. 8a and 8b). The rate at which $X_{\mathrm{e}}$ changes depends largely on two properties: the initial value of $\left[X_{\mathrm{e}}\right]_{\mathrm{i}}$ and the difference between end-member $\mathrm{MgO}-F$ and $T-F$ relationships. In the case of the former, low- $\left[X_{\mathrm{e}}\right]_{\mathrm{i}}$ systems experience proportionally more enrichment than high- $\left[X_{\mathrm{e}}\right]_{\mathrm{i}}$ systems. In the case of the latter, relative enrichments are considerable if the effects of major-element and $\mathrm{H}_{2} \mathrm{O}$ variability on $\mathrm{MgO}-F$ and $T-F$ systematics are correlated; shifts 
in $X_{\mathrm{e}}$ are more modest if they are driven by differences either in major-element or $\mathrm{H}_{2} \mathrm{O}$ contents alone.

Projecting $\mathrm{MgO}-X_{\mathrm{e}}$ paths into $\mathrm{MgO}-\mathrm{La}$ and $\mathrm{MgO}-\mathrm{La} / \mathrm{Yb}$ spaces shows that bulk trends in natural Icelandic data can be broadly reproduced by the independent differentiation, eruption and sampling of primitive melts with a $\left[X_{\mathrm{e}}\right]_{\mathrm{i}}$ value close to $\sim 0.3$ (Figs. $8 \mathrm{c}$ and $8 \mathrm{~d}$ ). Although end-member melts are unlikely to differentiate wholly independently in nature (Maclennan, 2008a), it should be noted that the differing crystallisation efficiencies of variably enriched primitive melts can both elevate average ITE contents and fractionate some ITE ratios in large datasets. However, comparable projections into $\mathrm{MgO}-\mathrm{Nb} / \mathrm{Zr}$ space are unable to account for the variability present in natural Icelandic data because end-member $\mathrm{Zr}$ contents are more fractionated from each other than their Yb contents. (Supplementary Figs. A.6 and A.7). The simple calculations presented in Fig. 8 nevertheless demonstrate that the preferential survival of melts from lithologically enriched source domains can bias chemical proxies that are commonly used to invert magma compositions for melting conditions and source characteristics (Shorttle and Maclennan, 2011; Gale et al., 2014). Hence, the contribution of recycled material to basalt genesis may be overestimated by methods that rely on correcting differentiated compositions for the effects of fractional crystallisation or that use the ITE systematics of evolved melts to estimate the mean properties of unmixed primary melts (e.g., Till et al., 2012; Shorttle et al., 2014). Our findings thus reinforce the importance of using primitive $(\mathrm{MgO}>9 \mathrm{wt} . \%)$, plagioclase undersaturated basalts to investigate mantle properties and melting behaviour.

\section{Variable crystallisation efficiency in mid-ocean ridge basalts}

Geochemical variability is particularly well defined in Iceland, making it an excellent location for investigating the evolution of compositionally distinct primitive magmas. However, differences in crystallisation efficiency could arise in any setting where primary melts have variable major-element or $\mathrm{H}_{2} \mathrm{O}$ contents. For example, neither melting processes nor source characteristics are uniform throughout the global mid-ocean ridge system, resulting in considerable heterogeneity in primary MORB compositions (Klein and Langmuir, 1987; 
Kinzler and Grove, 1992; Gale et al., 2014; O'Neill and Jenner, 2016). Primitive MORB glass compositions from the global database of Gale et al. (2013) show considerable variability in $\mathrm{Al}_{2} \mathrm{O}_{3}$ contents and $\mathrm{Ca} / \mathrm{Na}$ values, $14-18$ wt.\% and 2-4 respectively, at a constant $\mathrm{MgO}$ content of $\sim 9$ wt.\% (Fig. 9a and 9b). Similar degrees of compositional heterogeneity have also been resolved in regional studies on the Pacific Ocean (Michael and Chase, 1987), where primary depletions in $\mathrm{Ca}$ and $\mathrm{Al}$ have been linked with enrichments in ITE and $\mathrm{H}_{2} \mathrm{O}$ contents, defining a pattern of correlated geochemical variability similar to that observed in Iceland (Shorttle and Maclennan, 2011; Hartley et al., 2015). However, simply extending the findings of our experiments on Icelandic systems to MORB systems is hampered by spatial variations in geochemical systematics along the mid-ocean ridge system (e.g., Schilling, 1973; Dupré and Allègre, 1983). We therefore used calculations with the MELTS algorithm (performed using the alphaMELTS frontend) to explore whether MORB systems could be affected by differences in crystallisation efficiency comparable to those observed in our model systems from Iceland (Ghiorso and Sack, 1995; Smith and Asimow, 2005).

\subsection{Incompatible trace element over-enrichment in MORB}

Calculations with the MELTS algorithm capture the first-order $T-F-X$ trends in our experimental dataset (Fig. 5). That is, although MELTS simulations typically underestimate absolute differences in $F$ evolution between end-member systems, the key experimental observation that depleted primitive melts crystallise more efficiently than enriched primitive melts is reproduced, even if the effects on ITE systematics are somewhat muted (Supplementary Fig. A.8). We thus investigated the $T-F-X$ evolution of geochemically variable primitive MORB compositions by performing fractional crystallisation simulations for all the near-primary glass compositions (i.e. >9 wt.\%) in the Gale et al. (2013) database for which ITE analyses were reported. For simplicity and internal consistency, all calculations were performed at $150 \mathrm{MPa}$ and an $f_{\mathrm{O}_{2}}$ buffered at QFM-0.2 (Sinton and Detrick, 1992; Zhang et al., 2018). Although the degree of $\mathrm{H}_{2} \mathrm{O}$ enrichment in MORB varies spatially along the mid-ocean ridge system (Michael, 1995), we approximated melt $\mathrm{H}_{2} \mathrm{O}$ contents from their Ce contents using a fixed $\mathrm{H}_{2} \mathrm{O} / \mathrm{Ce}$ of 200. Melt ITE contents were modelled with parti- 
tion coefficients implemented in the alphaMELTS software (McKenzie and O'Nions, 1991; Blundy and Wood, 1994; McKenzie and O’Nions, 1995; Wood and Blundy, 1997).

Our alphaMELTS calculations show that different primitive MORB compositions evolve along compositionally distinct liquid lines of descent (LLDs). Initially Al-rich compositions typically saturate in plagioclase at higher melt $\mathrm{MgO}$ contents than initially Al-poor compositions, often resulting in rapid decreases in melt $\mathrm{Al}_{2} \mathrm{O}_{3}$ content as a function of melt $\mathrm{MgO}$ content (Fig. 9a). This trend is directly comparable with observations on both our experiments (Fig. 4c) and natural basalts from the Pacific Ocean (Michael and Chase, 1987). In contrast, the preservation of $\mathrm{Ca} / \mathrm{Na}$ variability in different LLDs is less distinct (Fig. $9 \mathrm{~b})$. However, the combined effects of major-element and $\mathrm{H}_{2} \mathrm{O}$ variability on the evolution of $F$ are striking (Figs. 9c and $9 d$ ). Specifically, $F$ falls at markedly different rates with decreasing melt $\mathrm{MgO}$ content and $T$ for different primitive melts. For example, our calculations indicate an $F$ range at a melt $\mathrm{MgO}$ content of 8 wt.\% (i.e. $F_{8}$ ) of approximately 0.48-0.98; comparable spreads in $F$ can be observed in isothermal slices through $F-T$ space at $<1200{ }^{\circ} \mathrm{C}$. These differences in $F_{8}$ are primarily driven by differences in the timing of plagioclase saturation: low- $F_{8}$ compositions have high initial melt $\mathrm{Al}_{2} \mathrm{O}_{3}$ contents that promote plagioclase stability (Fig. 9e) - olivine-only crystallisation has a negligible effect on $F$. There is also a weak positive correlation between $F_{8}$ and initial $\mathrm{La} / \mathrm{Yb}$ values, indicating that crystallisation efficiency may correlate with ITE and $\mathrm{H}_{2} \mathrm{O}$ enrichment as it does in our experiments on Icelandic model systems (Fig. 9f). A relationship between melt $\mathrm{Al}_{2} \mathrm{O}_{3}$ content and $\mathrm{La} / \mathrm{Yb}$ is nonetheless present, with ITE-depleted melts having initially high $\mathrm{Al}_{2} \mathrm{O}_{3}$ contents that are swiftly reduced by extensive plagioclase crystallisation (Fig. 9a).

The rate at which the ITE content of residual MORB liquids increases as a function of differentiation degree is typically considered to be greater than can be achieved by fractional crystallisation alone (Bryan et al., 1976). This apparent over-enrichment has been invoked as evidence for MORB genesis by replenishment-mixing-tapping-crystallisation in steadystate reservoirs (O'Hara, 1977; O'Neill and Jenner, 2012), the entrainment of mushes that have experienced in situ crystallisation (Langmuir, 1989; Coogan and O'Hara, 2015) and the concurrent mixing and crystallisation of melts with initially high degrees of compositional 
variability (Shorttle et al., 2016). Importantly, these models often assume that MORB differentiation can be modelled satisfactorily with a single $\mathrm{MgO}-F$ relationship. However, geochemically distinct primitive MORB compositions experience different rates of mass loss during cooling (Fig. 9c and 9d), meaning that incompletely mixed MORB liquids evolving from different parental melts will become richer in ITEs at rates commensurate with their specific major-element and $\mathrm{H}_{2} \mathrm{O}$ contents (Fig. 7). Evaluating the origin of apparent trace element over-enrichments in MORB suites is thus highly sensitive to the assumptions made when modelling crystallisation. For example, our findings suggest that over-enrichment trends in averaged global datasets could result from the preferential survival and sampling of enriched compositions as magmatic evolution proceeds. While we do not question the abundant evidence for magma mixing playing a central role in MORB genesis (e.g., Dungan and Rhodes, 1978; Costa et al., 2010; Shorttle, 2015), we note that our proposed mechanism for modifying the composition distribution of evolving basalt populations is independent of plumbing system architecture, making it universally applicable; no long-lived melt lens is required for dry, depleted melts to crystallise at depths and temperatures at which hydrous, enriched melts are able to persist (cf. O'Neill and Jenner, 2012). Moreover, differences in F arise at melt $\mathrm{MgO}$ contents higher than those at which primary melt heterogeneity would be fully eradicated by mixing (>8 wt.\%; Shorttle, 2015). Therefore, average trends in global MORB data may at least in part represent a mean LLD of compositionally distinct liquids that become progressively biased towards enriched compositions as differentiation proceeds and mixing becomes more efficient.

\subsection{Crystal cargoes and crustal structure at mid ocean ridges}

Anorthitic plagioclase $\left(X_{\mathrm{An}}>0.8\right)$ is commonly observed in oceanic basalts from which it cannot have crystallised (Bryan, 1983; Grove et al., 1992; Nielsen et al., 1995; Lange et al., 2013; Neave et al., 2013). Combining our experimental findings and MELTS simulations of MORB differentiation reinforces previous interpretations that high- $X_{\text {An }}$ plagioclase in oceanic settings crystallises from Ca- and Al-rich melts (Fig. 10; Grove et al., 1992; Panjasawatwong et al., 1995; Kohut and Nielsen, 2004). As discussed above, primitive melts 
with these major-element characteristics are typically associated with ITE depletions (Fig. 9; Michael and Chase, 1987). Moreover, high- $X_{\text {An }}$ plagioclase crystals themselves often record growth from melts more depleted than their carrier liquids (Halldórsson et al., 2008; Lange et al., 2013; Neave et al., 2014, 2015). The anorthitic crystal cargoes carried by some oceanic basalts thus feasibly constitute the entrained remnants of depleted magmas which crystallised at depth and contributed little liquid mass to the magmas that brought them to the surface. High- $X_{\text {An }}$ plagioclase crystals may therefore be widespread markers of depleted and otherwise cryptic melts generated by high-degree melting of lherzolitic sources.

Cumulates provide parallel evidence for the progressive biasing of residual MORB liquids towards enriched compositions. For example, clinopyroxene core compositions from the uniquely well-sampled Hess Deep rift section through the East Pacific Rise crust show increasing chondrite-normalised $\mathrm{Ce} / \mathrm{Yb}$ values as functions of both decreasing $\mathrm{Mg} \#_{\text {cpx }}$ and decreasing stratigraphic height that cannot be explained by simple fractional crystallisation - ITEs cannot be fractionated to the required degree (Lissenberg et al., 2013). Although this trend has been taken as evidence for reactive porous flow controlling cumulate (and hence MORB) compositions (Lissenberg and MacLeod, 2016), we speculate that the preferential survival of enriched primary melts during magmatic evolution may also play a role. Plutonic rocks from mid-ocean ridge settings may thus complement and balance the bias towards enriched compositions observed in the volcanic record. Indeed, the crust must host the depleted, crystalline counterparts to enriched melts that have erupted onto the ocean floor unless significant amounts of crystallisation takes place in the mantle. The deep and efficient crystallisation of depleted melts from refractory sources may thus account for the apparent absence of the isotopically ultradepleted compositions noted in xenoliths and abyssal peridotites from erupted archives (Stracke et al., 2011; Byerly and Lassiter, 2014; Burton et al., 2017).

\section{Summary}

By performing crystallisation experiments on synthetic analogues of geochemically distinct Icelandic basalts we have demonstrated that the compositional paths along which 
primitive melts evolve depend strongly on their initial major-element and $\mathrm{H}_{2} \mathrm{O}$ contents. Importantly, the rate at which cooling melts lose mass by crystallisation, i.e. their crystallisation efficiency, is contingent on the compositional properties they inherit from the mantle. Specifically, depleted melts generated by high-degree melting of initially fertile lherzolites attain higher crystallinities for any given drop in $T$ or melt $\mathrm{MgO}$ content than enriched melts sourced from recycled and potentially pyroxenitic lithologies. These differences in crystallisation efficiency stem primarily from the depression of mineral - and in particular plagioclase - liquidi by the combined effects of $\mathrm{Na}$ and $\mathrm{H}_{2} \mathrm{O}$ enrichment, and $\mathrm{Al}$ and $\mathrm{Ca}$ depletion in ITE-enriched systems.

Our experimental findings show that the ITE systematics of geochemically heterogeneous basalts cannot be modelled using simple LLDs with uniquely defined $\mathrm{MgO}-F$ and $T-F$ relationships. We illustrate that some features in natural data from Iceland can be accounted for by variations in the crystallisation efficiency of compositionally distinct primary basalts. Although magma mixing undoubtedly plays a major role in controlling erupted basalt compositions, we demonstrate that basalt compositions can also be modified by differences in $\mathrm{MgO}-F$ arising across a differentiation interval where mixing is unlikely to have proceeded to completion. Specifically, we show that the preferential survival of enriched melts during cooling and crystallisation progressively biases mean evolved compositions towards those from enriched and feasibly recycled mantle sources.

Calculations with the MELTS algorithm indicate that compositional heterogeneity in primitive MORB glasses is sufficiently extensive to propagate into significant variations in crystallisation efficiency. The depression of mineral liquidi in enriched systems offers a previously underexplored explanation for the apparent over-enrichment of ITEs in differentiating MORB liquids that is independent of magma reservoir architecture; ITE over-enrichment may be rooted in the mantle rather than the magma reservoir. Evidence of ITE and isotopic depletion in cumulate and exhumed mantle rocks suggests that there are deep depleted reservoirs that balance volcanic archives biased towards ITE enrichment. Moreover, high- $X_{\mathrm{An}}$ plagioclase cargoes and ITE-depleted cumulate rocks testify to the widespread crystallisation of depleted melts deep within the crust. 
Overall, we have shown that our understanding of melting and compositional heterogeneity in the mantle is probably skewed by interpreting an erupted record unlikely to represent the full spectrum of primary melts produced at depth. Although we focussed on Iceland because of its suitability for in-depth study and MORB because of its global significance, feedbacks between primary melt compositions, phase equilibrium relations and sampling biases are likely to be important in myriad geological settings. Understanding the filtering effects of lithospheric thermal structure on the geochemical systematics of erupted basalts represents a crucial next step in using observations from the Earth's surface to map its deep chemical structure.

\section{Acknowledgements}

We thank Harald Behrens, Renat Almeev, Stefan Linsler, Robert Balzer, Julian Fiege and Ulrich Kroll for their assistance with experiments and analyses. We thank Eric Brown and Deborah Eason for their supportive and constructive comments, Marc Hirschmann and an anonymous reviewer for their helpful comments on an earlier version of this manuscript and Rajdeep Dasgupta for his efficient editorial handling. This work and D.A.N. were supported by the Alexander von Humboldt Foundation, the German Research Foundation (NE2097/11) and a Presidential Fellowship from the University of Manchester. F.H. acknowledges support from the the German Research Foundation (HO1337/35-1). D.A.N. devised the project and carried out the experiments with the guidance of O.N. and F.H. All authors contributed towards the interpretation of experimental data and the intellectual development of the written manuscript. 

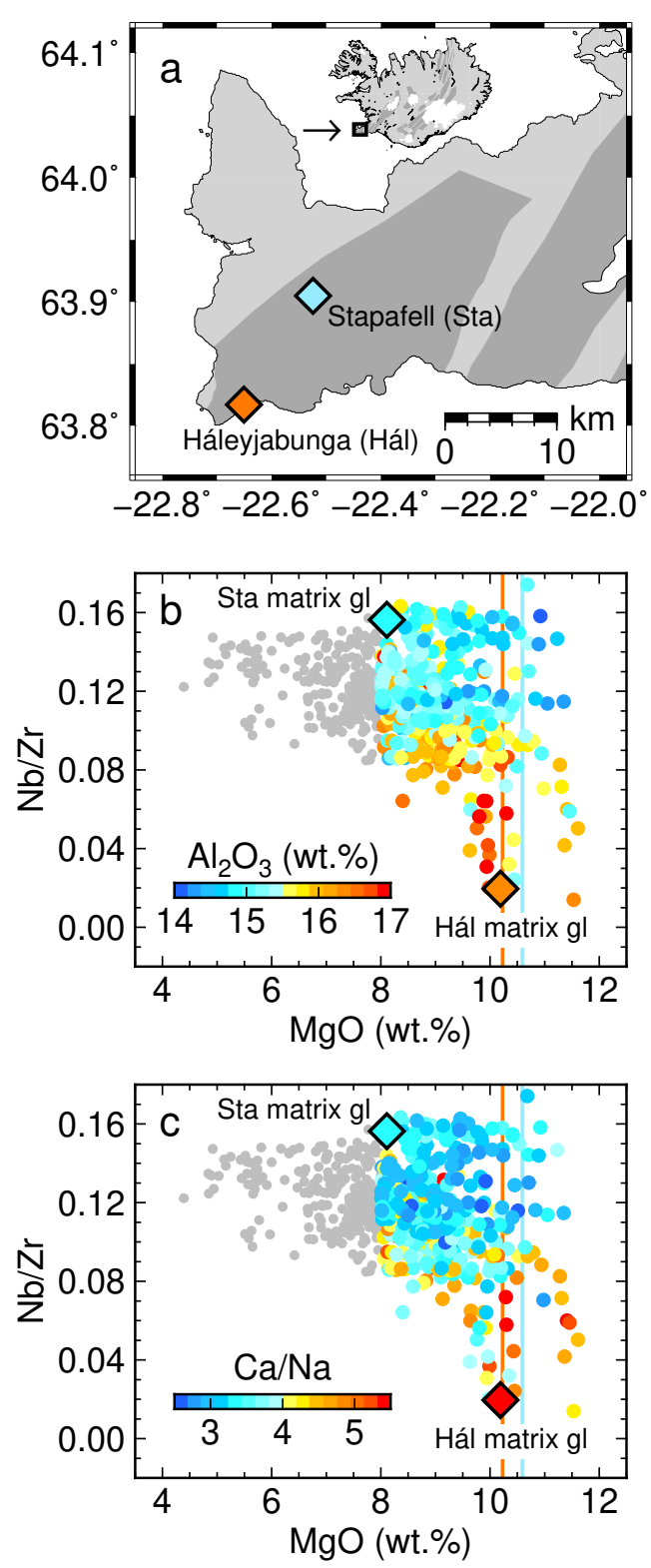

Figure 1: The geographical and geochemical context for our experimental work. (a) Map showing the locations of the Háleyjabunga (Hál) and Stapafell (Sta) lavas on the Reykjanes Peninsula of southwest Iceland. (b and c) Plots summarising the major- and trace-element systematics of glass and whole-rock samples from the Reykjanes Peninsula and Western Volcanic Zone of southwest Iceland. All data are from the collation of Shorttle and Maclennan (2011). $\mathrm{MgO}$ is a measure of differentiation degree and $\mathrm{Nb} / \mathrm{Zr}$ a measure of incompatible-trace-element (ITE) enrichment. High-MgO samples are coloured to highlight variability in their (b) $\mathrm{Al}_{2} \mathrm{O}_{3}$ contents and (c) $\mathrm{Ca} / \mathrm{Na}$ values (expressed throughout as molar ratios). Matrix glass compositions from Háleyjabunga and Stapafell are shown. Vertical coloured lines show the $\mathrm{MgO}$ contents of fractionation-corrected synthetic analogues of Háleyjabunga (orange) and Stapafell (blue) matrix glasses used as experimental starting materials. 


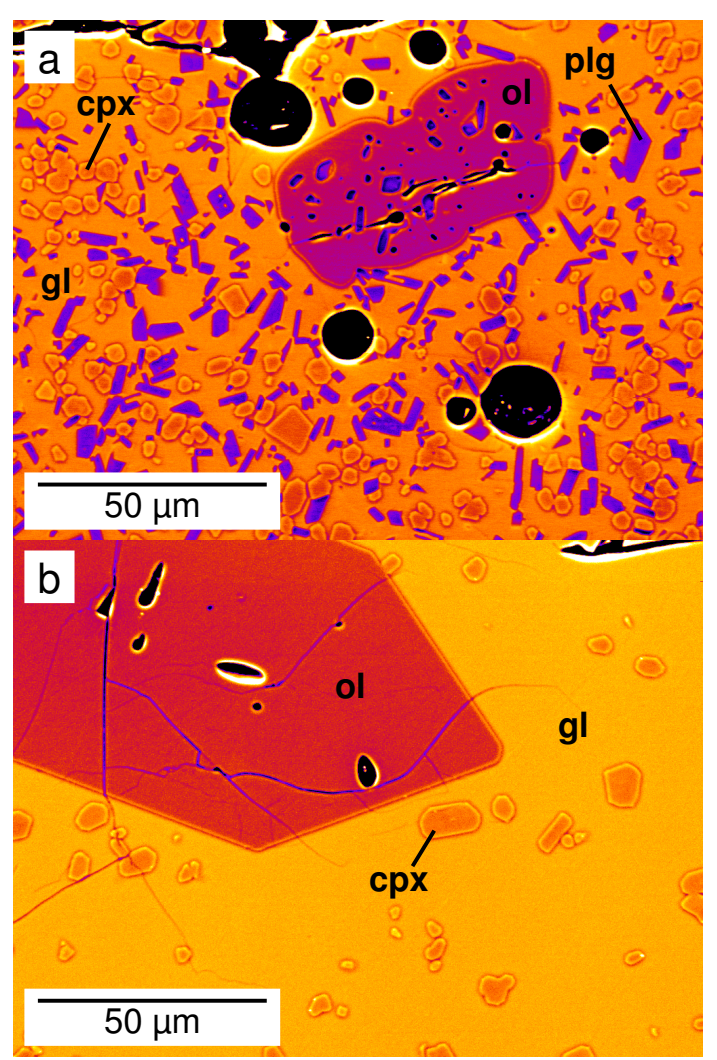

Figure 2: Backscattered electron images of experimental samples produced concurrently in Fe-presaturated $\mathrm{Au}_{80} \mathrm{Pd}_{20}$ capsules run at $300 \mathrm{MPa}$ and $1200{ }^{\circ} \mathrm{C}$ for 48 hours. Phases are labelled as follows: gl, glass; ol, olivine; plg, plagioclase; and cpx, clinopyroxene. (a) Products of experiment Y0166-6 on the depleted Háleyjabunga analogue. (b) Products of experiment Y0166-9 on the enriched Stapafell analogue. 

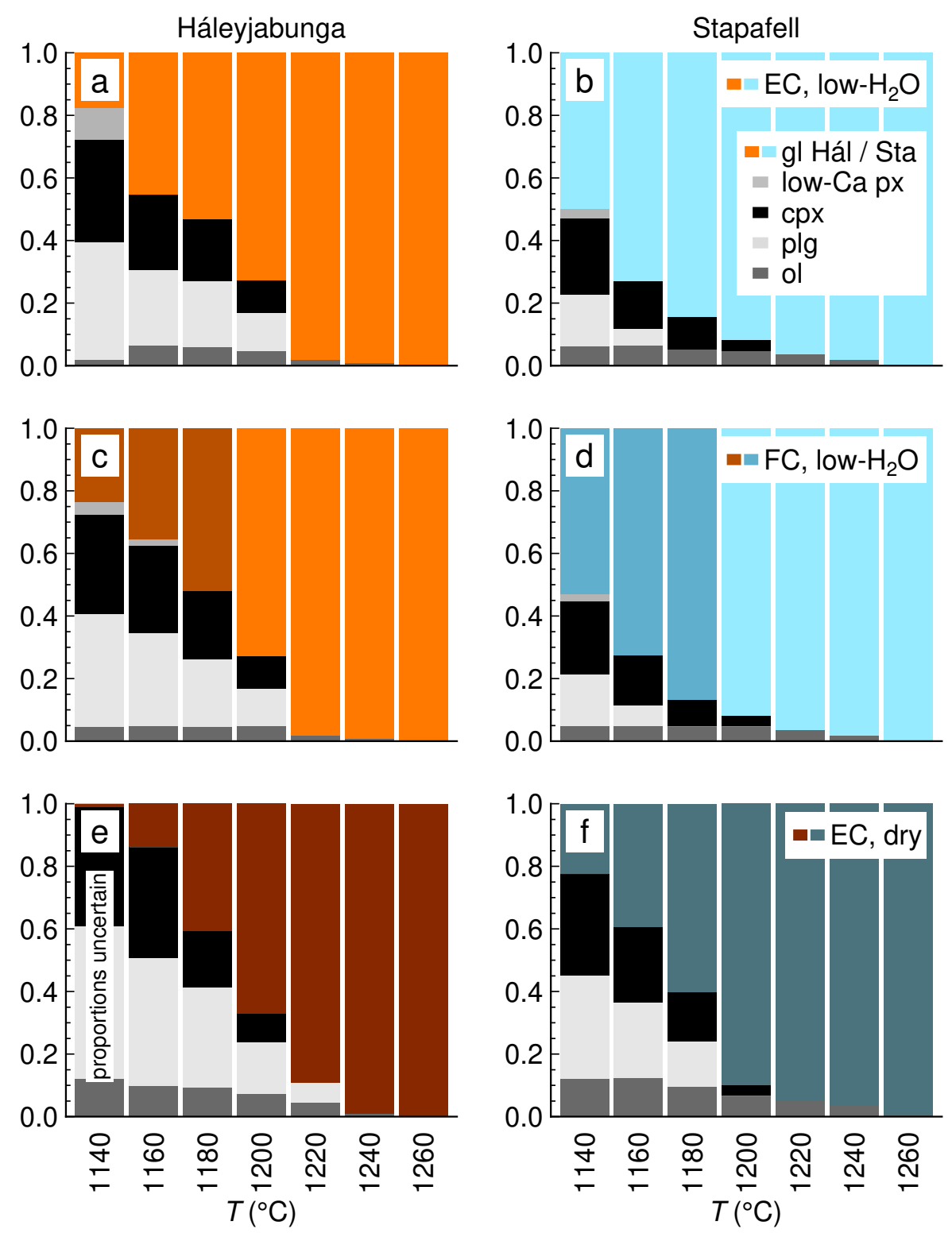

Figure 3: Phase proportions in experimental products as a function of experimental temperature $(T)$. Phases are labelled as follows: gl, glass; ol, olivine; plg, plagioclase; cpx, clinopyroxene; low-Ca px, low-Ca pyroxene. ( $\mathrm{a}$ and b) Phase proportions in the products of equilibrium crystallisation (EC) experiments on (a) depleted Háleyjabunga (Hál) and (b) enriched Stapafell (Sta) analogues under low- $\mathrm{H}_{2} \mathrm{O}$ conditions (initial $\mathrm{H}_{2} \mathrm{O} \sim$ 0.5 wt.\%) in $\mathrm{Au}_{80} \mathrm{Pd}_{20}$ capsules. (c and d) Cumulative phase proportions in the products of near-fractional crystallisation (FC) experiments carried out on (c) Hál and (d) Sta analogues under low- $\mathrm{H}_{2} \mathrm{O}$ conditions in $\mathrm{Au}_{80} \mathrm{Pd}_{20}$ capsules. Experiments below $1200{ }^{\circ} \mathrm{C}$ were performed using starting materials synthesised to match glass compositions measured in the products of runs at $1200{ }^{\circ} \mathrm{C}$. (e and f) Phase proportions in the products of EC experiments carried out on (e) Hál and (f) Sta analogues under dry conditions (initial $\mathrm{H}_{2} \mathrm{O}$ $\sim 0.1$ wt.\%) in graphite-Pt double capsules. 

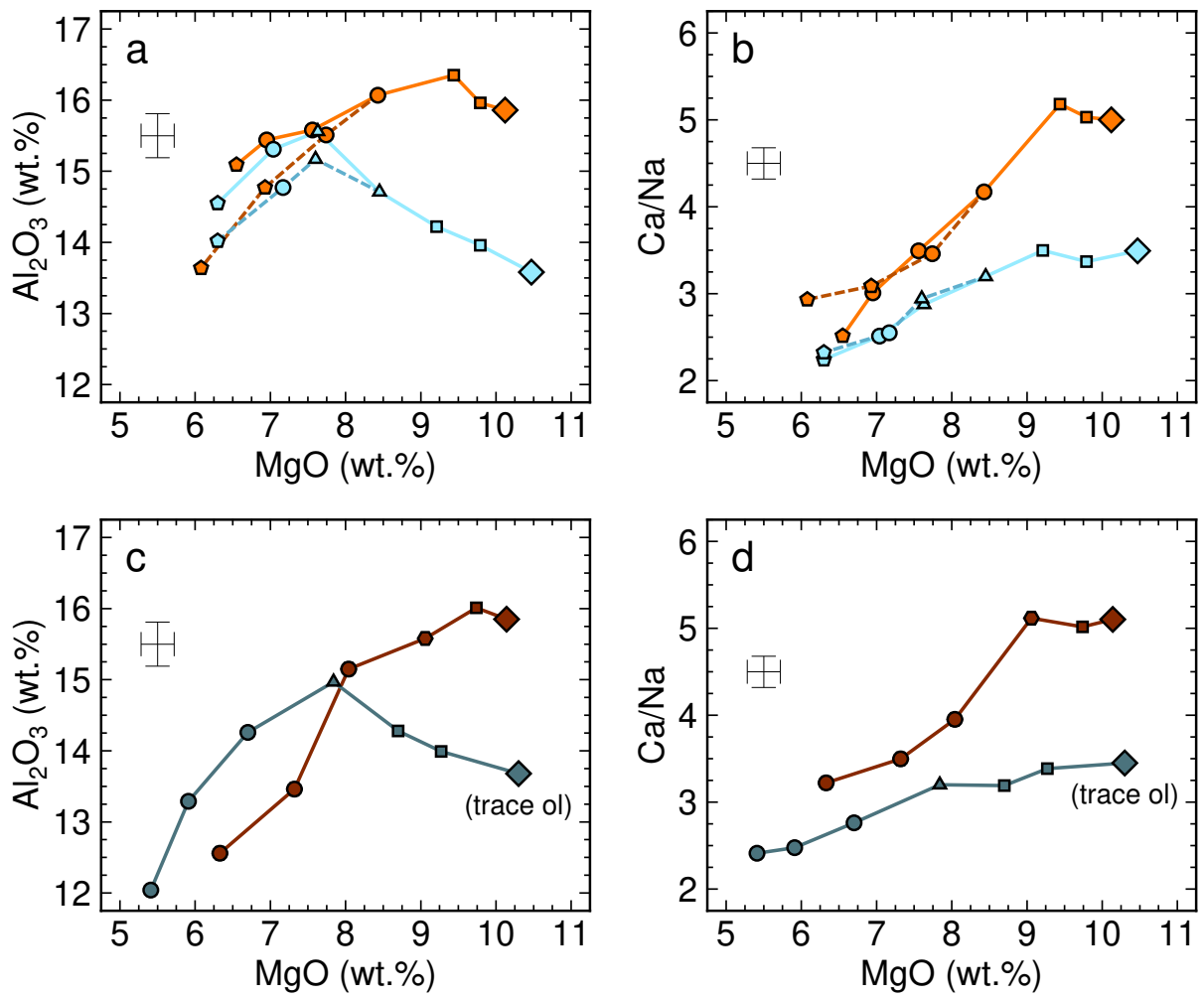

$\begin{array}{ccc}\text { - Hál EC low- } \mathrm{H}_{2} \mathrm{O} & --- \text { Hál FC low- } \mathrm{H}_{2} \mathrm{O} & \text { - Hál EC dry } \\ \text { - Sta EC low- } \mathrm{H}_{2} \mathrm{O} & --- \text { Sta FC low- } \mathrm{H}_{2} \mathrm{O} & \text { - Sta EC dry }\end{array}$

Cumulative phase assemblages

$\diamond \mathrm{gl}( \pm \mathrm{Cr}-\mathrm{sp}) \quad$ a $\mathrm{gl}+\mathrm{ol}( \pm \mathrm{Cr}-\mathrm{sp}) \quad \circ \mathrm{gl}+\mathrm{ol}+\mathrm{plg} \quad \Delta \mathrm{gl}+\mathrm{ol}+\mathrm{cpx}$

$\circ \mathrm{gl}+\mathrm{ol}+\mathrm{plg}+\mathrm{cpx}$

$\circ \mathrm{gl}+\mathrm{ol}+\mathrm{plg}+\mathrm{cpx}+\mathrm{low}-\mathrm{Ca} \mathrm{px}$

Figure 4: Experimentally determined liquid lines of decent (LLDs) summarised on plots of MgO versus (a and c) $\mathrm{Al}_{2} \mathrm{O}_{3}$ and ( $\mathrm{b}$ and d) $\mathrm{Ca} / \mathrm{Na}$. The products of experiments on depleted Háleyjabunga (Hál) and enriched Stapafell (Sta) analogues are shown in orange and blue hues respectively. Phases are labelled as follows: gl, glass; Cr-sp, Cr-spinel; ol, olivine; plg, plagioclase; cpx, clinopyroxene; low-Ca px, low-Ca pyroxene. Characteristic $2 \sigma$ analytical uncertainties are shown. (a and b) Equilibrium (EC) and nearfractional (FC) crystallisation experiments carried out under low- $\mathrm{H}_{2} \mathrm{O}$ conditions (initial $\mathrm{H}_{2} \mathrm{O} \sim 0.5$ wt.\%) in $\mathrm{Au}_{80} \mathrm{Pd}_{20}$ capsules. (c and d) EC experiments carried out under dry conditions (initial $\mathrm{H}_{2} \mathrm{O} \sim 0.1$ wt.\%) in graphite-Pt double capsules. 

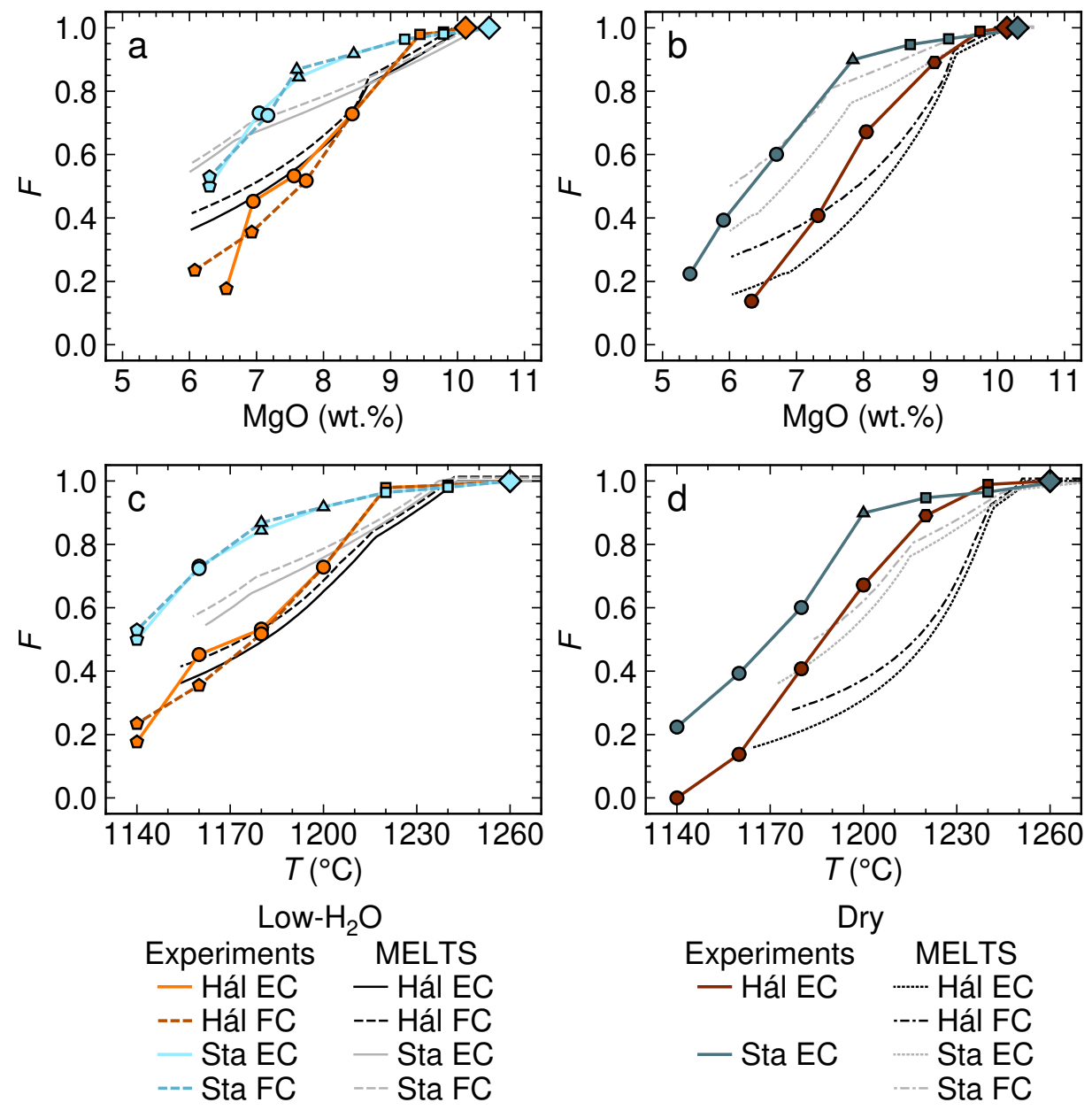

Figure 5: Evolution of melt fraction $(F)$ in experimental products. Maximum uncertainties in $F$ estimated from the summed residuals of mass balance calculations do not exceed the size of plot symbols. (a and b) Evolution of $F$ as a function of melt $\mathrm{MgO}$ content for experiments carried out under (a) low- $\mathrm{H}_{2} \mathrm{O}$ and (b) dry conditions on Icelandic end-member analogues. Symbols are the same as in Fig. 4. MgO-F trends calculated with the MELTS algorithm are shown for comparison (Ghiorso and Sack, 1995; Smith and Asimow, 2005). (c and d) Evolution of $F$ as a function of $T$ for the same experiments carried out under (c) low- $\mathrm{H}_{2} \mathrm{O}$ and (d) dry conditions, also shown with trends from calculations with the MELTS algorithm. 

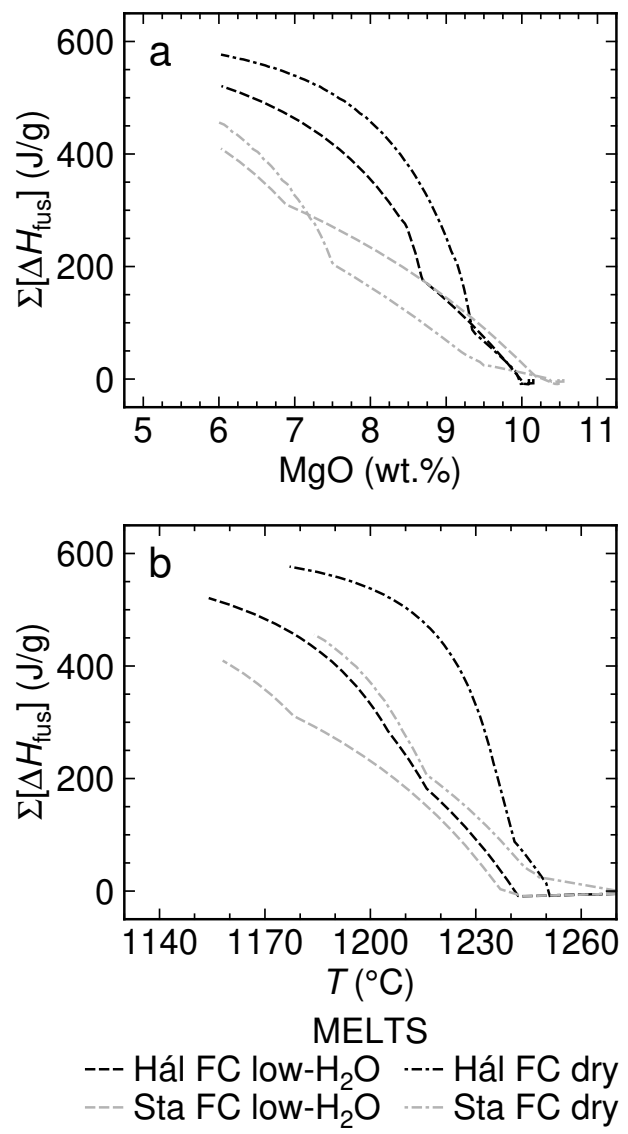

Figure 6: Estimates of heat release from evolving Icelandic end-member basalts. (a) Evolution of total heat released per unit mass of initially supplied melt (expressed as $\Sigma\left[\Delta \mathrm{H}_{\text {fus }}\right]$ ) as a function of melt $\mathrm{MgO}$ content taken from calculations with the MELTS algorithm (e.g., Shorttle et al., 2016). (b) Evolution of $\Sigma\left[\Delta \mathrm{H}_{\text {fus }}\right]$ as a function of $T$. 

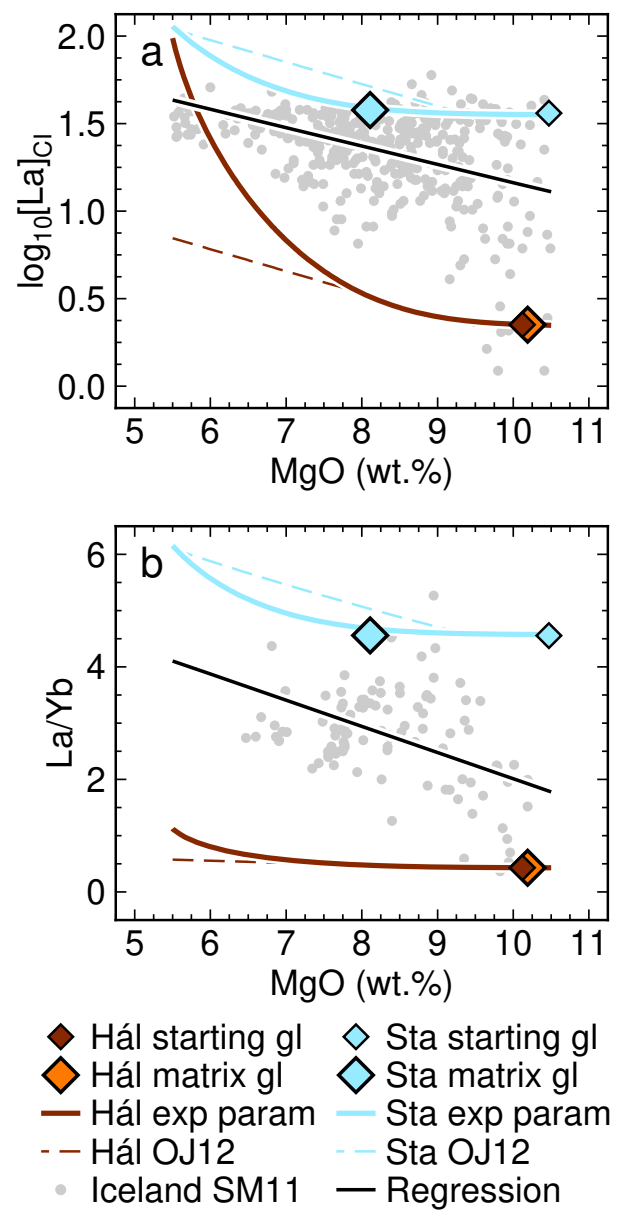

Figure 7: Comparing ITE evolution trends predicted using our experimental findings with natural data from Iceland. (a) Log-linear plots of MgO-La systematics of glass and whole-rock samples from southwest Iceland plotted (Shorttle and Maclennan, 2011) (SM11). A regression through the natural data is shown with a solid black line. The compositions of end-member Icelandic matrix glasses and synthetic analogues are shown as large and small coloured diamonds respectively. Solid lines show the evolution of melt La contents predicted from the Rayleigh fractionation equation using a constant partition coefficient from O'Neill and Jenner (2012) (OJ12) and end-member-specific MgO-F relationships parametrised using our experiments on depleted Háleyjabunga and enriched Stapafell analogues under dry and low- $\mathrm{H}_{2} \mathrm{O}$ conditions respectively. Dashed lines show equivalent predictions made using the $\mathrm{MgO}-F$ relationship given by O'Neill and Jenner (2012). (b) $\mathrm{MgO}-\mathrm{La} / \mathrm{Yb}$ systematics of glass and whole-rock samples from southwest Iceland with the results of calculations equivalent to those shown in (a). 

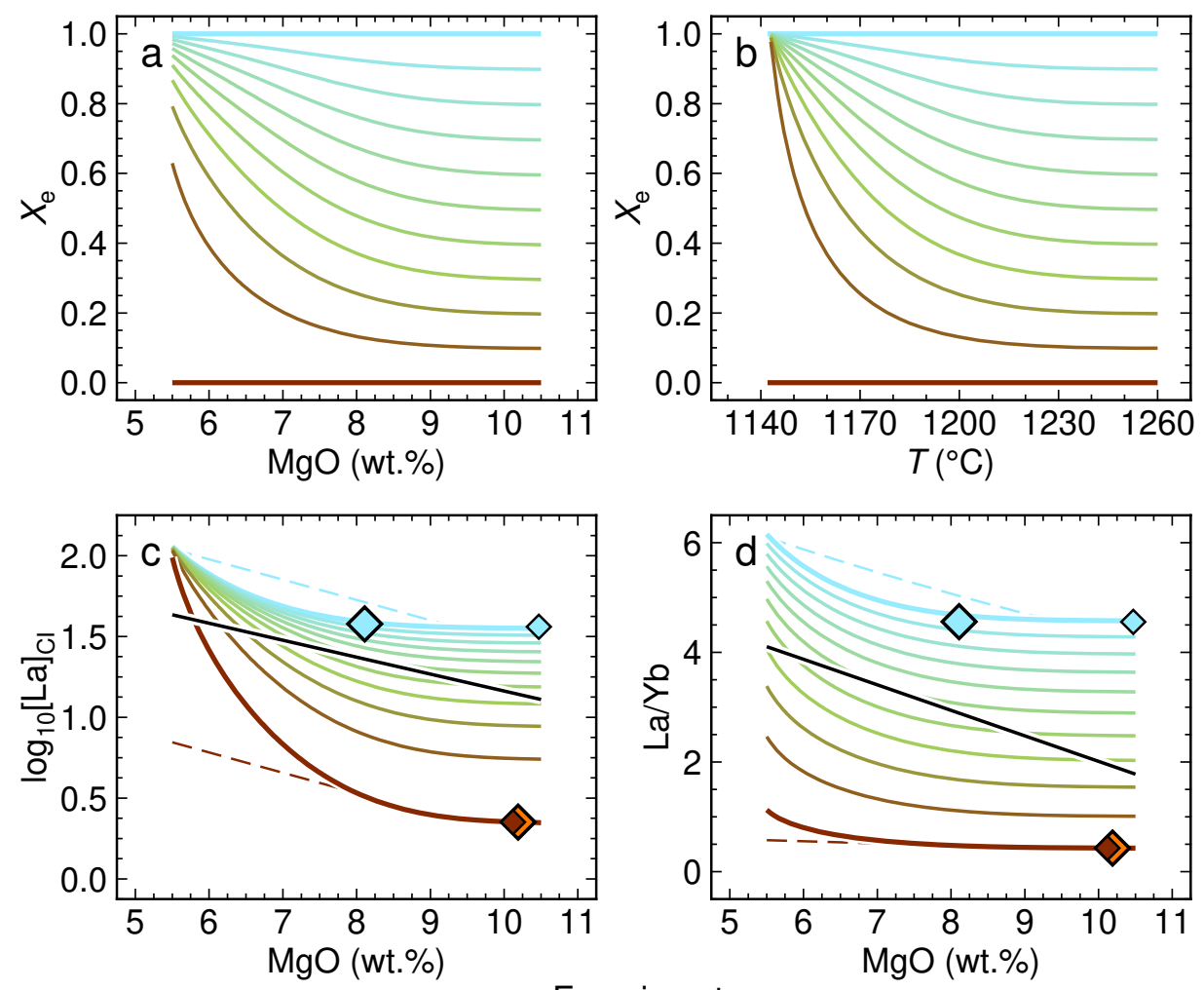

Hál starting gl $\diamond$ Hál matrix gl - Hál exp param - - Hál OJ12 - Regression
Experiments

$\diamond$ Sta starting gl $\checkmark$ Sta matrix gl Sta exp param Sta OJ12

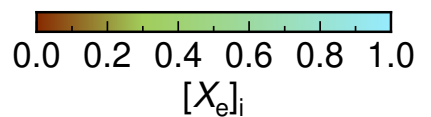

Figure 8: Biasing of evolved basalt compositions towards melts from enriched sources. ( $a$ and b) Plots showing how the proportion of melts from a low- $\mathrm{H}_{2} \mathrm{O}$, enriched end-member source $\left(X_{\mathrm{e}}\right)$ evolves as a function of the initial relative abundance of these enriched melts $\left(\left[X_{\mathrm{e}}\right]_{\mathrm{i}}\right)$ with respect to depleted melts and decreasing (a) melt $\mathrm{MgO}$ content or (b) $T$. For any given $\left[X_{\mathrm{e}}\right]_{i}$ greater than zero (i.e. the case where all melts are from a dry, depleted end-member), the mean $X_{\mathrm{e}}$ of remaining melts steadily increases because dry, depleted melts crystallise to a higher degree than low- $\mathrm{H}_{2} \mathrm{O}$, enriched melts for any given decrease in $\mathrm{MgO}$ or $T$. Note that these calculations make the simplifying assumption that no mixing takes place during magmatic evolution, i.e. end-member melts evolve in isolation of each other (cf., Maclennan, 2008a; Shorttle et al., 2016). (c and d) Plots showing how melt (c) La and (d) La/Yb evolve as functions of $\left[X_{\mathrm{e}}\right]_{\mathrm{i}}$ and MgO. Melt evolution trajectories were calculated using the same methods as those to construct Fig. 7. End-member compositions, regressions through natural data and melt evolution trajectories predicted using the $\mathrm{MgO}-F$ relationship given by O'Neill and Jenner (2012) (OJ12) are reproduced from Fig. 7 for context. 

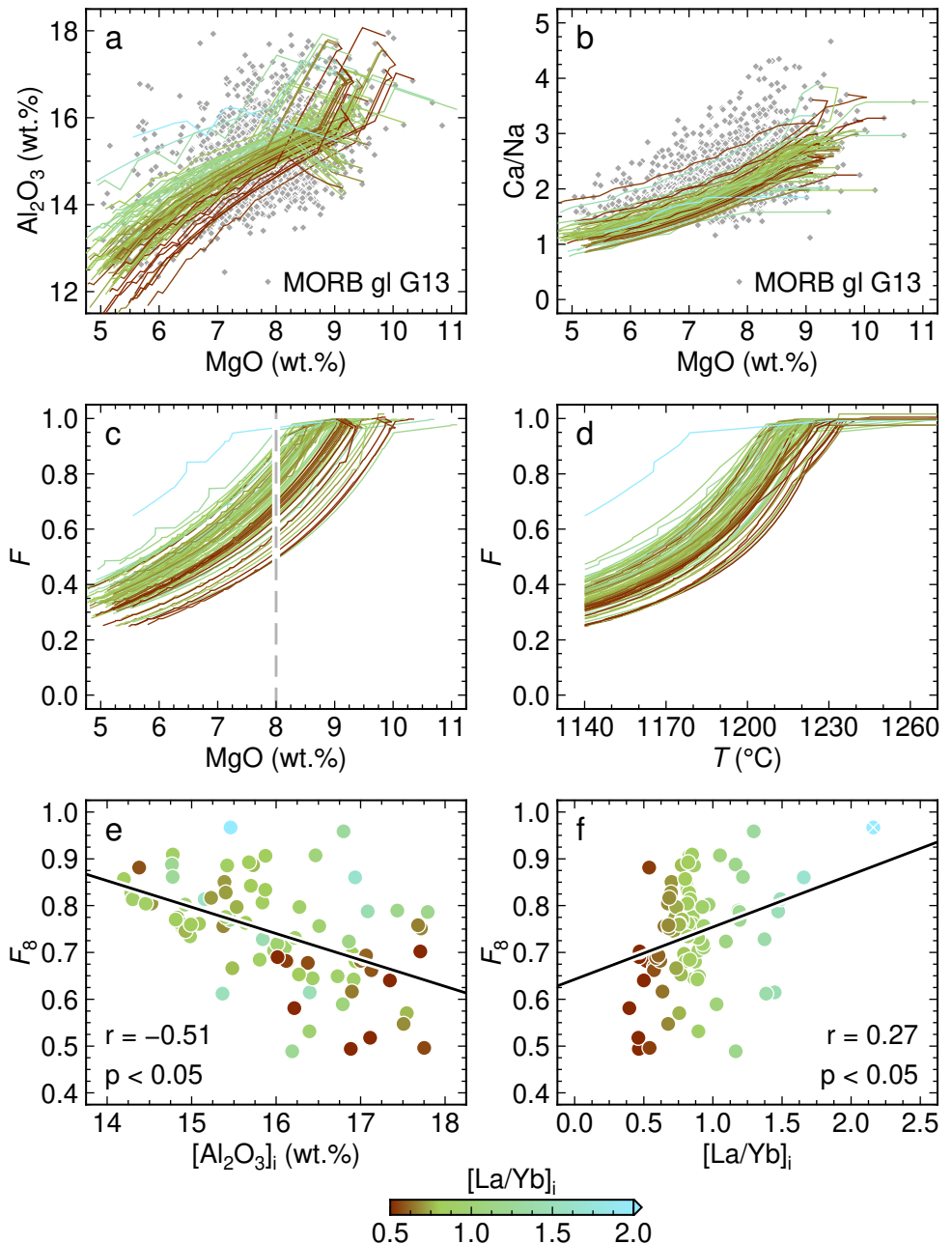

Figure 9: The effect of geochemical heterogeneity on crystallisation efficiency in MORB systems. ( $a$ and b) Plots summarising the major element systematics of global mid-ocean ridge basalt (MORB) glass compositions collated by Gale et al. (2013) (G13). At any given MgO content, MORB glasses exhibit considerable variability in both (a) $\mathrm{Al}_{2} \mathrm{O}_{3}$ contents and (b) $\mathrm{Ca} / \mathrm{Na}$ values. Coloured lines show LLDs of primitive (MgO $>9$ wt.\%) MORB glasses calculated using the MELTS algorithm (Ghiorso and Sack, 1995; Smith and Asimow, 2005). Calculations were performed at $150 \mathrm{MPa}$ (Sinton and Detrick, 1992), an oxygen fugacity $0.2 \log$ units below the quartz-fayalite-magnetite buffer (Zhang et al., 2018) and using melt $\mathrm{H}_{2} \mathrm{O}$ contents estimated from glass Ce contents by assuming a constant $\mathrm{H}_{2} \mathrm{O} / \mathrm{Ce}$ value of 200 (Michael, 1995). LLDs are coloured by their initial $\mathrm{La} / \mathrm{Yb}$ values $\left([\mathrm{La} / \mathrm{Yb}]_{\mathrm{i}}\right)$. (c and $\mathrm{d}$ ) Plots illustrating variability in $F$ as functions of (c) melt $\mathrm{MgO}$ content and (d) $T$. Note that the crystallisation of olivine and Cr-spinel has comparatively little effect on $F$. (e) A plot demonstrating how calculated values of $F$ at a melt $\mathrm{MgO}$ content of 8 wt.\% ( $\left.F_{8}\right)$ correlate negatively and significantly with initial melt $\mathrm{Al}_{2} \mathrm{O}_{3}$ contents $\left(\left[\mathrm{Al}_{2} \mathrm{O}_{3}\right]_{\mathrm{i}}\right)$. A regression through the data is shown with a black line; associated $\mathrm{r}$ - and p-values are also shown. (f) A plot illustrating the modest but significant positive correlation between ITE enrichment $\left([\mathrm{La} / \mathrm{Yb}]_{\mathrm{i}}\right)$ and $F_{8}$ in crystallising MORB that mirrors the more robust trend in southwest Iceland (Fig. 5). Regression data are shown as in (e); the highest- $[\mathrm{La} / \mathrm{Yb}]_{\mathrm{i}}$ point was excluded from the regression. 

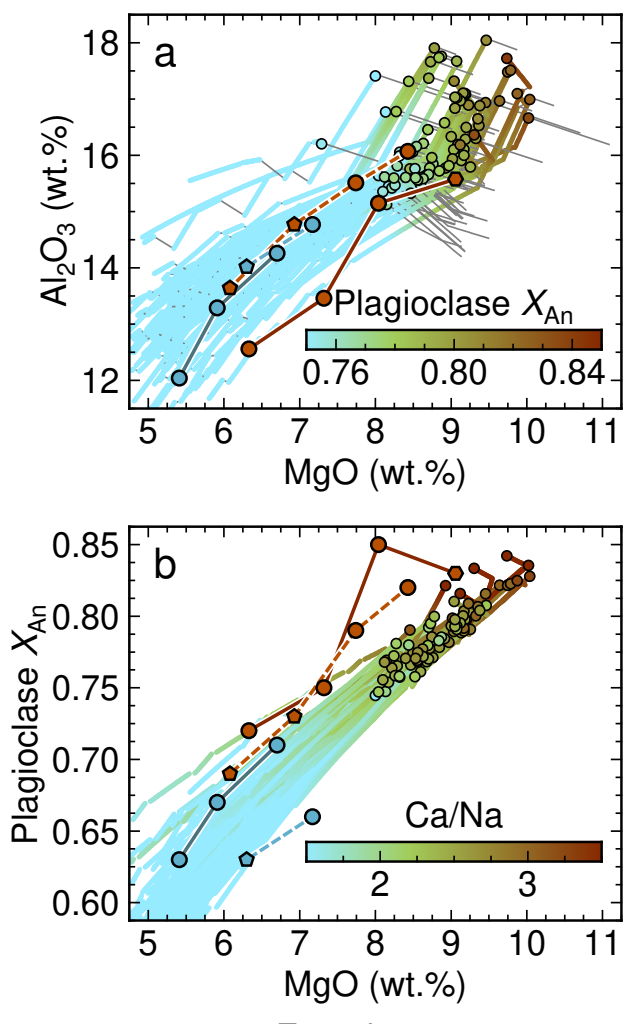

Experiments

- Hál EC dry --- Hál FC low- $\mathrm{H}_{2} \mathrm{O}$

- Sta EC dry --- Sta FC low- $\mathrm{H}_{2} \mathrm{O}$

Figure 10: High-anorthite plagioclase cargoes record the crystallisation of depleted melts. (a) LLDs of primitive $(\mathrm{MgO}>9$ wt.\%) MORB glasses calculated using the MELTS algorithm and coloured by the anorthite content $\left(X_{\mathrm{An}}\right.$, where $X_{\mathrm{An}}=$ molar $\left.\mathrm{Ca} /(\mathrm{Ca}+\mathrm{Na}+\mathrm{K})\right)$ of equilibrium plagioclase once plagioclase joins the liquidus assemblage (Ghiorso and Sack, 1995; Smith and Asimow, 2005). Plagioclase-free intervals of melt evolution are shown as thin grey lines. The first appearance of plagioclase along each LLD is highlighted with a black-outlined circle. (b) A plot comparing the evolution of $X_{\mathrm{An}}$ as a function of melt $\mathrm{MgO}$ content in MELTS simulations of primitive MORB evolution with our experimentally determined relationships from southwest Iceland. In our experiments, plagioclase forms at both a higher melt $\mathrm{MgO}$ content and with a higher $X_{\text {An }}$ during the crystallisation of dry, depleted melts than during the crystallisation of low- $\mathrm{H}_{2} \mathrm{O}$, enriched melts at otherwise similar conditions. 
Almeev, R. R., Holtz, F., Koepke, J., Parat, F., 2012. Experimental calibration of the effect of $\mathrm{H}_{2} \mathrm{O}$ on plagioclase crystallization in basaltic melt at $200 \mathrm{MPa}$. American Mineralogist 97, 1234-1240.

Almeev, R. R., Holtz, F., Koepke, J., Parat, F., Botcharnikov, R. E., 2007. The effect of $\mathrm{H}_{2} \mathrm{O}$ on olivine crystallization in MORB: Experimental calibration at 200 MPa. American Mineralogist 92 (4), 670-674.

Asimow, P. D., Langmuir, C. H., 2003. The importance of water to oceanic mantle melting regimes. Nature 421 (6925), 815-820.

Bali, E., Hartley, M. E., Halldórsson, S. A., Guðfinnsson, G. H., Jakobsson, S., 2018. Melt inclusion constraints on volatile systematics and degassing history of the 2014-2015 Holuhraun eruption, Iceland. Contributions to Mineralogy and Petrology 173, 9 .

Barr, J. A., Grove, T. L., 2010. AuPdFe ternary solution model and applications to understanding the $f_{\mathrm{O}_{2}}$ of hydrous, high-pressure experiments. Contributions to Mineralogy and Petrology 160 (5), 631-643.

Berndt, J., Liebske, C., Holtz, F., Freise, M., Nowak, M., Ziegenbein, D., Hurkuck, W., Koepke, J., 2002. A combined rapid-quench and $\mathrm{H}_{2}$-membrane setup for internally heated pressure vessels: Description and application for water solubility in basaltic melts. American Mineralogist 87 (11-12), 1717-1726.

Blundy, J. D., Wood, B. J., 1994. Prediction of crystal-melt partition coefficients from elastic moduli. Nature 372 (6505), 452-454.

Brown, E. L., Lesher, C. E., 2014. North Atlantic magmatism controlled by temperature, mantle composition and buoyancy. Nature Geoscience 7 (11), 820-824.

Bryan, W. B., 1983. Systematics of modal phenocryst assemblages in submarine basalts: Petrologic implications. Contributions to Mineralogy and Petrology 83 (1-2), 62-74.

Bryan, W. B., Thompson, G., Frey, F. A., Dickey, J. S., 1976. Inferred geologic settings and differentiation in basalts from the Deep-Sea Drilling Project. Journal of Geophysical Research 81 (23), 4285-4304.

Burton, K. W., Parkinson, I., Schiano, P., Gannoun, A., Laubier, M., 2017. The record of mantle heterogeneity preserved in Earth's oceanic crust. In: American Geophysical Union, Fall Meeting. pp. V51D-0384.

Byerly, B. L., Lassiter, J. C., 2014. Isotopically ultradepleted domains in the convecting upper mantle: Implications for MORB petrogenesis. Geology 42 (3), 203-206.

Chase, C. G., 1981. Oceanic island Pb: Two-stage histories and mantle evolution. Earth and Planetary Science Letters 52 (2), 277-284.

Condomines, M., Grönvold, K., Hooker, P. J., Muehlenbachs, K., O’Nions, R. K., Óskarsson, N., Oxburgh, E. R., 1983. Helium, oxygen, strontium and neodymium isotopic relationships in Icelandic volcanics. Earth and Planetary Science Letters 66, 125-136.

Coogan, L. A., O'Hara, M. J., 2015. MORB differentiation: In situ crystallization in replenished-tapped magma chambers. Geochimica et Cosmochimica Acta 158, 147-161.

Costa, F., Coogan, L. A., Chakraborty, S., 2010. The time scales of magma mixing and mingling involv- 
ing primitive melts and melt-mush interaction at mid-ocean ridges. Contributions to Mineralogy and Petrology 159 (3), 371-387.

Danyushevsky, L. V., Plechov, P., 2011. Petrolog3: Integrated software for modeling crystallization processes. Geochemistry, Geophysics, Geosystems 12 (7).

Dick, H. J. B., Fisher, R. L., Bryan, W. B., 1984. Mineralogic variability of the uppermost mantle along mid-ocean ridges. Earth and Planetary Science Letters 69 (1), 88-106.

Dungan, M. A., Rhodes, J. M., 1978. Residual Glasses and Melt Inclusions in Basalts from DSDP Legs 45 and 46: Evidence for Magma Mixing. Contributions to Mineralogy and Petrology 67 (4), 417-431.

Dupré, B., Allègre, C. J., 1983. Pb-Sr isotope variation in Indian Ocean basalts and mixing phenomena. Nature 303 (5913), 142-146.

Elthon, D., Scarfe, C. M., 1984. High-pressure phase equilibria of a high-magnesia basalt and the genesis of primary oceanic basalts. American Mineralogist 69, 1-15.

Feig, S. T., Koepke, J., Snow, J. E., 2010. Effect of oxygen fugacity and water on phase equilibria of a hydrous tholeiitic basalt. Contributions to Mineralogy and Petrology 160 (4), 551-568.

Gaetani, G. A., Grove, T. L., 1998. The influence of water on melting of mantle peridotite. Contributions to Mineralogy and Petrology 131 (4), 323-346.

Gale, A., Dalton, C. A., Langmuir, C. H., Su, Y., Schilling, J. G., 2013. The mean composition of ocean ridge basalts. Geochemistry, Geophysics, Geosystems 14 (3), 489-518.

Gale, A., Langmuir, C. H., Dalton, C. A., 2014. The Global Systematics of Ocean Ridge Basalts and their Origin. Journal of Petrology 55 (6), 1051-1082.

Ghiorso, M. S., 1997. Thermodynamic models of igneous processes. Annual Reviews of Earth and Planetary Sciences 25, 221-241.

Ghiorso, M. S., Sack, R. O., 1995. Chemical mass transfer in magmatic processes IV. A revised and internally consistent thermodynamic model for the interpolation and extrapolation of liquid-solid equilibria in magmatic systems at elevated temperatures and pressures. Contributions to Mineralogy and Petrology $119(2-3), 197-212$.

Grove, T. L., Bryan, W. B., 1983. Fractionation of pyroxene-phyric MORB at low pressure: An experimental study. Contributions to Mineralogy and Petrology 84 (4), 293-309.

Grove, T. L., Kinzler, R. J., Bryan, W. B., 1992. Fractionation of Mid-Ocean Ridge Basalt (MORB). In: Mantle Flow and Melt Generation at Mid-Ocean Ridges, Geophysical Monograph 71. American Geophysical Union, Washington D.C., pp. 281-310.

Gurenko, A. A., Chaussidon, M., 1995. Enriched and depleted primitive melts included in olivine from Icelandic tholeiites: Origin by continuous melting of a single mantle column. Geochimica et Cosmochimica Acta 59 (14), 2905-2917. 
Halldórsson, S. A., Óskarsson, N., Grönvold, K., Sigurdsson, G., Sverrisdottir, G., Steinthórsson, S., 2008. Isotopic-heterogeneity of the Thjorsa lava-Implications for mantle sources and crustal processes within the Eastern Rift Zone, Iceland. Chemical Geology 255 (3-4), 305-316.

Hartley, M. E., Maclennan, J., 2018. Magmatic Densities Control Erupted Volumes in Icelandic Volcanic Systems. Frontiers in Earth Science 6, 29.

Hartley, M. E., Neave, D. A., Maclennan, J., Edmonds, M., Thordarson, T., 2015. Diffusive over-hydration of olivine-hosted melt inclusions. Earth and Planetary Science Letters 425, 168-178.

Hauri, E. H., 1996. Major-element variability in the Hawaiian mantle plume.

Herzberg, C., O'Hara, M. J., 2002. Plume-associated ultramafic magmas of phanerozoic age. Journal of Petrology 43 (10), 1857-1883.

Hirose, K., Kushiro, I., 1993. Partial melting of dry peridotites at high pressures: Determination of compositions of melts segregated from peridotite using aggregates of diamond. Earth and Planetary Science Letters 114 (4), 477-489.

Hirschmann, M. M., Stolper, E. M., 1996. A possible role for garnet pyroxenite in the origin of the "garnet signature" in MORB. Contributions to Mineralogy and Petrology 124, 185-208.

Hofmann, A. W., 1997. Mantle geochemistry: the message from oceanic volcanism. Nature 385 (6613), 219-229.

Hofmann, A. W., White, W. M., 1982. Mantle plumes from ancient oceanic crust. Earth and Planetary Science Letters 57 (2), 421-436.

Husen, A., Almeev, R. R., Holtz, F., 2016. The Effect of $\mathrm{H}_{2} \mathrm{O}$ and Pressure on Multiple Saturation and Liquid Lines of Descent in Basalt from the Shatsky Rise. Journal of Petrology 57, 309-344.

Jakobsson, S. P., Jónsson, J., Shido, F., 1978. Petrology of the western Reykjanes Peninsula, Iceland. Journal of Petrology 19 (4), 669-705.

Jarosewich, E., Gooley, R., Husler, J., 1987. Chromium Augite - A New Microprobe Reference Sample. Geostandards and Geoanalytical Research 11 (2), 197-198.

Jarosewich, E., Nelen, J. A., Norberg, J. A., 1980. Reference samples for electron microprobe analysis. Geostandards Newsletter 4 (1), 43-47.

Jennings, E. S., Holland, T. J. B., Shorttle, O., Maclennan, J., Gibson, S. A., 2016. The composition of melts from a heterogeneous mantle and the origin of ferropicrite: Application of a thermodynamic model. Journal of Petrology 57, 2289-2310.

Johnson, K. T. M., Dick, H. J. B., Shimizu, N., 1990. Melting in the oceanic upper mantle: An ion microprobe study of diopsides in abyssal peridotites. Journal of Geophysical Research 95 (B3), 2661.

Kinzler, R. J., Grove, T. L., 1992. Primary Magmas of Mid-Ocean Ridge Basalts 2. Applications. Journal of Geophysical Research 97 (B5), 6907-6925. 
Klein, E. M., Langmuir, C. H., 1987. Global Correlations of Ocean Ridge Basalt Chemistry with Axial Depth and Crustal Thickness. Journal of Geophysical Research 92 (B8), 8089.

Kogiso, T., Hirose, K., Takahashi, E., 1998. Melting experiments on homogeneous mixtures of peridotite and basalt: Application to the genesis of ocean island basalts. Earth and Planetary Science Letters 162 (1-4), $45-61$.

Kohut, E. J., Nielsen, R. L., 2004. Melt inclusion formation mechanisms and compositional effects in highAn feldspar and high-Fo olivine in anhydrous mafic silicate liquids. Contributions to Mineralogy and Petrology 147 (6), 684-704.

Kress, V. C., Carmichael, I. S. E., 1991. The compressibility of silicate liquids containing $\mathrm{Fe}_{2} \mathrm{O}_{3}$ and the effect of composition, temperature, oxygen fugacity and pressure on their redox states. Contributions to Mineralogy and Petrology 108 (1-2), 82-92.

Lange, A. E., Nielsen, R. L., Tepley, F. J., Kent, A. J. R., 2013. Diverse Sr isotope signatures preserved in mid-oceanic-ridge basalt plagioclase. Geology 41 (2), 279-282.

Langmuir, C. H., 1989. Geochemical consequences of in situ crystallization. Nature 340 (6230), 199-205.

Lissenberg, C. J., MacLeod, C. J., 2016. A Reactive Porous Flow Control on Mid-ocean Ridge Magmatic Evolution. Journal of Petrology 57 (11\&12), 2195-2220.

Lissenberg, C. J., MacLeod, C. J., Howard, K. A., Godard, M., 2013. Pervasive reactive melt migration through fast-spreading lower oceanic crust (Hess Deep, equatorial Pacific Ocean). Earth and Planetary Science Letters 361, 436-447.

Maclennan, J., 2008a. Concurrent mixing and cooling of melts under Iceland. Journal of Petrology 49 (11), 1931-1953.

Maclennan, J., 2008b. Lead isotope variability in olivine-hosted melt inclusions from Iceland. Geochimica et Cosmochimica Acta 72 (16), 4159-4176.

Maclennan, J., 2019. Mafic tiers and transient mushes: evidence from Iceland. Philosophical Transactions of the Royal Society A 377 (20180021), 1-20.

McKenzie, D., O'Nions, R. K., 1991. Partial melt distributions from inversion of rare earth element concentrations. Journal of Petrology 23, 1021-1091.

McKenzie, D., O'Nions, R. K., 1995. The source regions of Ocean Island. Journal of Petrology 36 (1), $133-159$

Médard, E., Grove, T. L., 2008. The effect of $\mathrm{H}_{2} \mathrm{O}$ on the olivine liquidus of basaltic melts: Experiments and thermodynamic models. Contributions to Mineralogy and Petrology 155 (4), 417-432.

Melekhova, E., Annen, C., Blundy, J. D., 2013. Compositional gaps in igneous rock suites controlled by magma system heat and water content. Nature Geoscience 6 (5), 385-390.

Michael, P. J., 1995. Evidence from trace elements and $\mathrm{H}_{2} \mathrm{O}$ for regionally distinctive sources of depleted 
MORB: Implications for evolution of the depleted mantle. Earth and Planetary Science Letters 131 (2), 301-320.

Michael, P. J., Chase, R. L., 1987. The influence of primary magma composition, $\mathrm{H}<\mathrm{sub}>2</ \mathrm{sub}>\mathrm{O}$ and pressure on mid-ocean ridge basalt differentiation. Contributions to Mineralogy and Petrology 96 (2), $245-263$.

Namur, O., Humphreys, M. C. S., Holness, M. B., 2014. Crystallization of interstitial liquid and latent heat buffering in solidifying gabbros: Skaergaard intrusion, Greenland. Journal of Petrology 55 (7), 1389-1427.

Neave, D. A., Maclennan, J., Hartley, M. E., Edmonds, M., Thordarson, T., 2014. Crystal storage and transfer in basaltic systems: the Skuggafjöll eruption, Iceland. Journal of Petrology 55 (12), 2311-2346.

Neave, D. A., Maclennan, J., Thordarson, T., Hartley, M. E., 2015. The evolution and storage of primitive melts in the Eastern Volcanic Zone of Iceland: the 10 ka Grímsvötn tephra series (i.e. the Saksunarvatn ash). Contributions to Mineralogy and Petrology 170 (8), 21.

Neave, D. A., Passmore, E., Maclennan, J., Fitton, J. G., Thordarson, T., 2013. Crystal-melt relationships and the record of deep mixing and crystallization in the AD 1783 Laki eruption, Iceland. Journal of Petrology 54 (8), 1661-1690.

Neave, D. A., Putirka, K. D., 2017. A new clinopyroxene-liquid barometer, and implications for magma storage pressures under Icelandic rift zones. American Mineralogist 102, 777-794.

Neave, D. A., Shorttle, O., Oeser, M., Weyer, S., Kobayashi, K., 2018. Mantle-derived trace element variability in olivines and their melt inclusions. Earth and Planetary Science Letters 483, 90-104.

Nielsen, R. L., Crum, J., Bourgeois, R., Hascall, K., Forsythe, L. M., Fisk, M. R., Christie, D. M., 1995. Melt inclusions in high-An plagioclase from the Gorda Ridge: an example of the local diversity of MORB parent magmas. Contributions to Mineralogy and Petrology 122, 34-50.

O'Hara, M. J., 1968. Are Ocean Floor Basalts Primary Magma? Nature 220, 683-686.

O'Hara, M. J., 1977. Geochemical evolution during fractional crystallisation of a periodically refilled magma chamber. Nature 266 (5602), 503-507.

O'Neill, H. S. C., Jenner, F. E., 2012. The global pattern of trace-element distributions in ocean floor basalts. Nature 491 (7426), 698-704.

O'Neill, H. S. C., Jenner, F. E., 2016. Causes of the compositional variability among ocean floor basalts. Journal of Petrology 57 (11\&12), 2163-2194.

Panjasawatwong, Y., Danyushevsky, L. V., Crawford, A. J., Harris, K. L., 1995. An experimental study of the effects of melt composition on plagioclase-melt equilibria at 5 and 10 kbar: implications for the origin of magmatic high-An plagioclase. Contributions to Mineralogy and Petrology 118 (4), 420-432.

Peate, D. W., Baker, J. A., Jakobsson, S. P., Waight, T. E., Kent, A. J. R., Grassineau, N. V., Skovgaard, A. C., 2009. Historic magmatism on the Reykjanes Peninsula, Iceland: A snap-shot of melt generation at 
a ridge segment. Contributions to Mineralogy and Petrology 157 (3), 359-382.

Phipps Morgan, J., 2001. Thermodynamics of pressure release melting of a veined plum pudding mantle. Geochemistry, Geophysics, Geosystems 2 (4), 2000GC000049.

Presnall, D. C., Dixon, S. A., Dixon, J. R., O'Donnell, T. H., Brenner, N. L., Schrock, R. L., Dycus, D. W., 1978. Liquidus Phase Relations on the Join Diopside-Forsterite-Anorthite from 1 atm to $20 \mathrm{kbar}$ : Their Bearing on the Generation and Crystallization of Basaltic Magma. Contributions to Mineralogy and Petrology 66 (2), 203-220.

R Development Core Team, 2008. R: A Language and Environment for Statistical Computing.

Schilling, J. G., 1973. Iceland Mantle Plume: Geochemical Study of Reykjanes Ridge. Nature 242 (5400), $565-571$.

Schuessler, J. A., Botcharnikov, R. E., Behrens, H., Misiti, V., Freda, C., 2008. Oxidation state of iron in hydrous phono-tephritic melts. American Mineralogist 93 (10), 1493-1504.

Shorttle, O., 2015. Geochemical variability in MORB controlled by concurrent mixing and crystallisation. Earth and Planetary Science Letters 424, 1-14.

Shorttle, O., Maclennan, J., 2011. Compositional trends of Icelandic basalts: Implications for short-length scale lithological heterogeneity in mantle plumes. Geochemistry, Geophysics, Geosystems 12 (11), 1-32.

Shorttle, O., Maclennan, J., Lambart, S., 2014. Quantifying lithological variability in the mantle. Earth and Planetary Science Letters 395, 24-40.

Shorttle, O., Moussallam, Y., Hartley, M. E., Maclennan, J., Edmonds, M., Murton, B. J., 2015. Fe-XANES analyses of Reykjanes Ridge basalts: Implications for oceanic crust's role in the solid Earth oxygen cycle. Earth and Planetary Science Letters 427, 272-285.

Shorttle, O., Rudge, J. F., Maclennan, J., Rubin, K. H., 2016. A Statistical Description of Concurrent Mixing and Crystallization during MORB Differentiation: Implications for Trace Element Enrichment. Journal of Petrology 57 (11\&12), 2127-2162.

Sinton, J. M., Detrick, R. S., 1992. Mid-ocean ridge magma chambers. Journal of Geophysical Research 97 (B1), 197-216.

Smith, P. M., Asimow, P. D., 2005. Adiabat-1ph: A new public front-end to the MELTS, pMELTS, and pHMELTS models. Geochemistry, Geophysics, Geosystems 6 (2), 1-8.

Soetaert, K., Van den Meersche, K., van Oevelen, D., 2009. limSolve: Solving Linear Inverse Models.

Stracke, A., 2012. Earth's heterogeneous mantle: A product of convection-driven interaction between crust and mantle. Chemical Geology 330-331, 274-299.

Stracke, A., Snow, J. E., Hellebrand, E., von der Handt, A., Bourdon, B., Birbaum, K., Günther, D., 2011. Abyssal peridotite Hf isotopes identify extreme mantle depletion. Earth and Planetary Science Letters 308 (3-4), 359-368. 
Till, C. B., Grove, T. L., Krawczynski, M. J., 2012. A melting model for variably depleted and enriched lherzolite in the plagioclase and spinel stability fields. Journal of Geophysical Research: Solid Earth $117(6), 1-23$.

Villiger, S., Ulmer, P., Müntener, O., 2007. Equilibrium and fractional crystallization experiments at 0.7 $\mathrm{GPa}$; the effect of pressure on phase relations and liquid compositions of tholeiitic magmas. Journal of Petrology 48 (1), 159-184.

Wager, L. R., Brown, G. M., Wadsworth, W. J., 1960. Types of igneous cumulates. Journal of Petrology $1(1), 73-85$.

Wallace, P. J., 1998. Water and partial melting in mantle plumes: Inferences from the dissolved $\mathrm{H}_{2} \mathrm{O}$ concentrations of Hawaiian basaltic magmas. Geophysical Research Letters 25 (19), 3639-3642.

Warren, J. M., 2016. Global variations in abyssal peridotite compositions. Lithos 248-251, 193-219.

Winpenny, B., Maclennan, J., 2011. A partial record of mixing of mantle melts preserved in Icelandic phenocrysts. Journal of Petrology 52 (9), 1791-1812.

Wood, B. J., Blundy, J. D., 1997. A predictive model for rare earth element partitioning between clinopyroxene and anhydrous silicate melt. Contributions to Mineralogy and Petrology 129 (2-3), 166-181.

Wright, T. L., Doherty, P. C., 1970. A linear programming and least squares computer method for solving petrologic mixing problems. Geological Society Of America Bulletin 81 (8), 1995-2008.

Zhang, H. L., Cottrell, E., Solheid, P. A., Kelley, K. A., Hirschmann, M. M., 2018. Determination of $\mathrm{Fe}^{3+} / \Sigma \mathrm{Fe}$ of XANES basaltic glass standards by Mössbauer spectroscopy and its application to the oxidation state of iron in MORB. Chemical Geology 479, 166-175.

Zindler, A., Hart, S. R., 1986. Chemical Geodynamics. Annual Reviews of Earth and Planetary Sciences $14(1), 493-571$.

\section{Appendix A. Methodological details}

\section{Appendix A.1. Experimental methods}

Nominally dry experiments were carried out by loading $\sim 30 \mathrm{mg}$ of each dried starting glass powder into two graphite capsules that were then encased pairwise within Pt outer capsules. Low- $\mathrm{H}_{2} \mathrm{O}$ experiments were carried out by loading $\sim 50 \mathrm{mg}$ of each dried starting glass powder into $\mathrm{Au}_{80} \mathrm{Pd}_{20}$ capsules that had first been pre-saturated with $\sim 0.25$ wt.\% Fe to minimise Fe loss to capsule materials (Gaetani and Grove, 1998). $\mathrm{Au}_{80} \mathrm{Pd}_{20}$ capsules then were bound together pairwise with Pt wire. 
Prepared capsules were suspended from a Pt wire in the hot zone of an internally heated pressure vessel (IHPV) at the Institut für Mineralogie of the Leibniz Universität Hannover, Germany (Berndt et al., 2002). All experiments were performed at $300 \mathrm{MPa}$ using an $\mathrm{Ar}$ pressure medium. Pressure was continuously monitored with a strain gauge manometer and did not vary more than the uncertainty of the manometer (5 MPa) during experimental runs. Experiments were performed in $20{ }^{\circ} \mathrm{C}$ steps between 1260 and $1140{ }^{\circ} \mathrm{C}$. Temperature was continuously monitored over the vessel's $25 \mathrm{~mm}$-high hot zone with four unsheathed S-type $\left(\mathrm{Pt}-\mathrm{Pt}_{90} \mathrm{Rh}_{10}\right)$ thermocouples and was typically within $5{ }^{\circ} \mathrm{C}$ of the target temperature. Run durations varied from 25 hours for the hottest superliquidus experiments to $72-117$ hours for the coolest crystal-rich experiments. Capsules were quenched at the end of experimental runs by fusing the Pt wires on which they were suspended, dropping them into a cold zone at base on the vessel.

\section{Appendix A.2. Analytical methods}

Experimental products (including capsules) were mounted in epoxy resin, polished and carbon coated for analysis by electron probe microanalysis (EPMA) with a Cameca SX100 instrument at the Institut für Mineralogie of the Leibniz Universität Hannover, Germany. Silicon, Ti, Al, Cr, Fe, Mn, Mg, Ca, Na, K and P were measured in glasses with a beam size of $10 \mu \mathrm{m}$ (occasionally $5 \mu \mathrm{m}$ in highly crystalline samples), an accelerating voltage of $15 \mathrm{kV}$ and a current of $10 \mathrm{nA}$. Silicon, Ti, Al, Cr, Fe, Mn, Mg, Ca, Na and K were measured in minerals with a beam size of $1 \mu \mathrm{m}$, an accelerating voltage of $15 \mathrm{kV}$ and a current of $15 \mathrm{nA}$. Gold, $\mathrm{Pd}$ and Fe were measured in capsules with a beam size of $1 \mu \mathrm{m}$, an accelerating voltage of $15 \mathrm{kV}$ and a current of $40 \mathrm{nA}$. Elements were counted on peak for $20 \mathrm{~s}$, with the exceptions of $\mathrm{Si}$ and $\mathrm{Na}$ that were counted on peak for $10 \mathrm{~s}$ to minimise drift and Na migration. Background counting times were half of the on-peak counting times. The following standards were used for calibration: wollastonite ( $\mathrm{Si}$ and $\mathrm{Ca}$ ), $\mathrm{TiO}_{2}(\mathrm{Ti}), \mathrm{Al}_{2} \mathrm{O}_{3}(\mathrm{Al}), \mathrm{Cr}_{2} \mathrm{O}_{3}(\mathrm{Cr}$ ), $\mathrm{Fe}_{2} \mathrm{O}_{3}$ (for Fe in silicates and Cr-spinel), Fe metal (for Fe in capsules), $\mathrm{Mn}_{3} \mathrm{O}_{4}(\mathrm{Mn}$ ), $\mathrm{MgO}$ $(\mathrm{Mg})$, albite $(\mathrm{Na})$, orthoclase $(\mathrm{K})$, apatite $(\mathrm{P}), \mathrm{Au}$ metal $(\mathrm{Au})$ and $\mathrm{Pd}$ metal $(\mathrm{Pd})$. To ensure internal consistency across multiple sessions, analyses were normalised as follows: 
glass analyses were normalised to VG-2 basalt glass (NMNH 111240-52; using the preferred $\mathrm{MgO}$ content); clinopyroxene, low-Ca pyroxene and plagioclase analyses were normalised to Kakanui augite (NMNH 122142; using preferred values); olivine analyses were normalised to San Carlos olivine (NMNH 111312-44); and chromite analyses were normalised to Tiebaghi Mine chromite (NMNH 117075) (Jarosewich et al., 1980). Accuracy and precision were monitored by measuring the following standards that were also normalised for each analytical session: A-99 basaltic glass (NMNH 113498), Ney County Cr-augite (NMNH 164905) and Lake County plagioclase (NMNH 115900) (Jarosewich et al., 1980, 1987). Major (>1 wt.\%) and minor (<1 wt.\%) elements were determined with accuracies better than $2 \%$ and $10 \%$, and $1 \sigma$ precisions better than $2 \%$ and $15 \%$ respectively. Typical analyses of standards are provided alongside analyses of experimental products in the Supplementary Material.

Glass $\mathrm{H}_{2} \mathrm{O}$ concentrations were determined in experimental products with low crystal contents by Fourier-transform infrared (FTIR) spectroscopy with a Bruker IFS88 instrument at the Institut für Mineralogie of the Leibniz Universität Hannover, Germany (e.g., Husen et al., 2016). Experimental glasses produced at $1260{ }^{\circ} \mathrm{C}$ under nominally dry conditions contain $0.09 \pm 0.00(1 \sigma)$ wt. $\% \mathrm{H}_{2} \mathrm{O}$, whereas glasses produced at $1240-1260{ }^{\circ} \mathrm{C}$ under low$\mathrm{H}_{2} \mathrm{O}$ conditions contain $0.40 \pm 0.04(1 \sigma)$ wt. $\% \mathrm{H}_{2} \mathrm{O}$.

\section{Appendix A.3. Experimental oxygen fugacities}

When imposing no solid buffer, the IHPV used has an intrinsic $f_{\mathrm{O}_{2}}$ slightly above the QFM buffer (Husen et al., 2016). Nominally dry experimental glasses produced in graphitePt double capsules were theoretically buffered at an $f_{\mathrm{O}_{2}}$ close to the carbon-carbon dioxide (CCO) buffer. Colorimetric analyses of nominally dry glasses produced at $1240-1260{ }^{\circ} \mathrm{C}$ returned variable $\mathrm{Fe}^{3+} / \Sigma \mathrm{Fe}$ contents of $0.09-0.19$, consistent with $f_{\mathrm{O}_{2}}$ conditions between QFM-1 and QFM+1 (Schuessler et al., 2008). However, these $\mathrm{Fe}^{3+} / \Sigma \mathrm{Fe}$ determinations were subject to large uncertainties because of the low $\mathrm{Fe}^{3+}$ content of graphite-buffered experimental glasses. Colorimetric analyses of low- $\mathrm{H}_{2} \mathrm{O}$ experimental glasses produced at $1240-1260{ }^{\circ} \mathrm{C}$ return more consistent $\mathrm{Fe}^{3+} / \Sigma \mathrm{Fe}$ values of $0.23 \pm 0.02(1 \sigma)$, which correspond to an $f_{\mathrm{O}_{2}}$ of $\mathrm{QFM}+1.5 \pm 0.3(1 \sigma)$ (Kress and Carmichael, 1991). $\mathrm{Au}_{80} \mathrm{Pd}_{20}$ capsule compositions 
indicate a comparable $f_{\mathrm{O}_{2}}$ of $\mathrm{QFM}+1.1 \pm 0.2(1 \sigma)$ (Barr and Grove, 2010).

822

823

824

\section{Appendix A.4. Estimating phase proportions}

Phase proportions were estimated from experimental glass and mineral compositions with a non-weighted least-squares mass balance approach (e.g., Wright and Doherty, 1970). Calculations were performed by balancing the composition of the starting glass against the composition of all phases observed in experimental products using the lsei() function of the limSolve package in R (R Development Core Team, 2008; Soetaert et al., 2009). Root mean square (rms) errors of least-squares calculations were always $<0.29$, which approximate to absolute maximum uncertainties in individual phase proportions of $\sim 0.03$. 


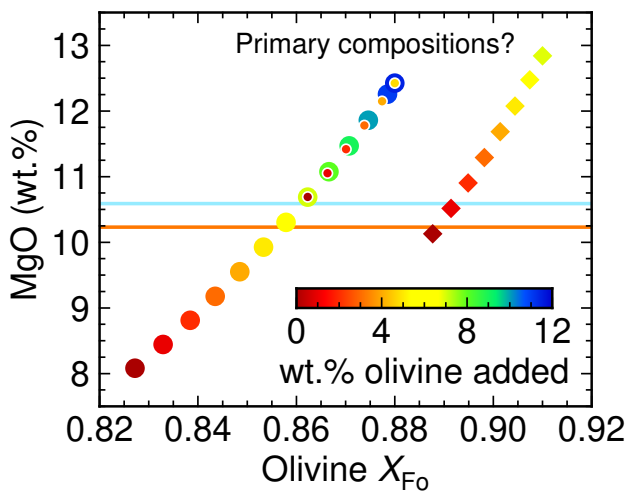

- Correcting Hál matrix gl to $X_{\mathrm{F}_{0}}=91$

- Correcting Sta matrix $\mathrm{gl}$ to $X_{\mathrm{Fo}}=88$

- Corrected Hál starting gl MgO

- Corrected Sta starting gl MgO

- Correcting Sta starting $\mathrm{gl}$ to $X_{\mathrm{Fo}}=88$

Figure A.1: The effect of correcting matrix glass (gl) compositions to putative primary compositions. The Stapafell (Sta) matrix glass composition was corrected to a similar melt MgO content as the Háleyjabunga (Hál) matrix glass before synthesising a starting glass by adding approximately $7 \mathrm{wt} . \%$ olivine using the Petrolog3 software package (Condomines et al., 1983; Herzberg and O'Hara, 2002; Danyushevsky and Plechov, 2011). Correcting Háleyjabunga and Stapafell starting glass compositions to be in equilibrium with the most primitive olivines in each of the eruptions requires the further addition of 7 and 5 wt.\% olivine respectively. Thus, correcting back to putative primary compositions would simply result in the depleted Háleyjabunga analogue experiencing an interval of olivine-only crystallisation at high temperatures that would not occur during cooling of the enriched Stapafell analogue, accentuating differences in $\mathrm{MgO}-F$ relationships between our model end-member systems. 


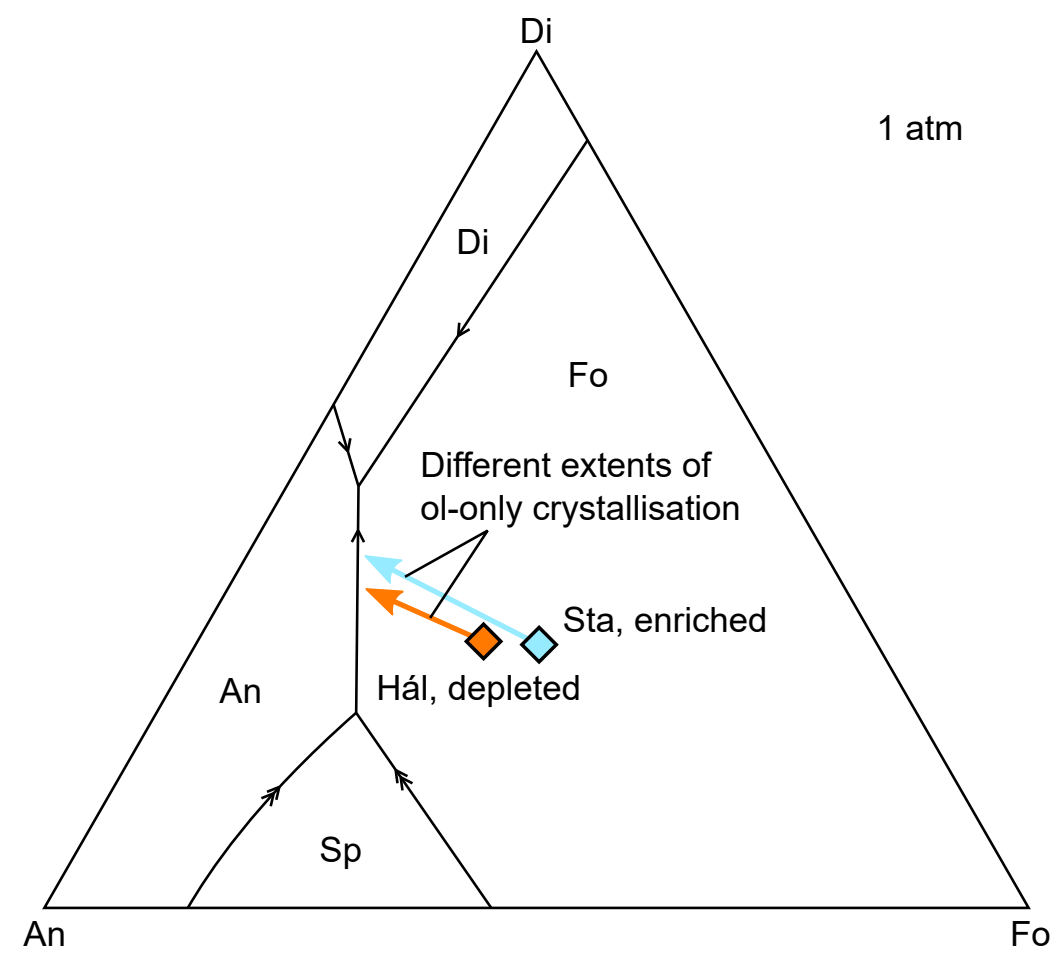

Figure A.2: Sketch phase diagram illustrating how refractory melts rich in $\mathrm{Ca}$ and $\mathrm{Al}$ reach multiple saturation at higher temperatures than enriched melts rich in $\mathrm{Na}$ and $\mathrm{Fe}$ because of their higher normative anorthite contents. Phase boundaries at $1 \mathrm{~atm}$ are reproduced from Presnall et al. (1978) and compositions from Háleyjabunga (Hál, depleted) and Stapafell (Sta, enriched) are shown only for illustrative. 

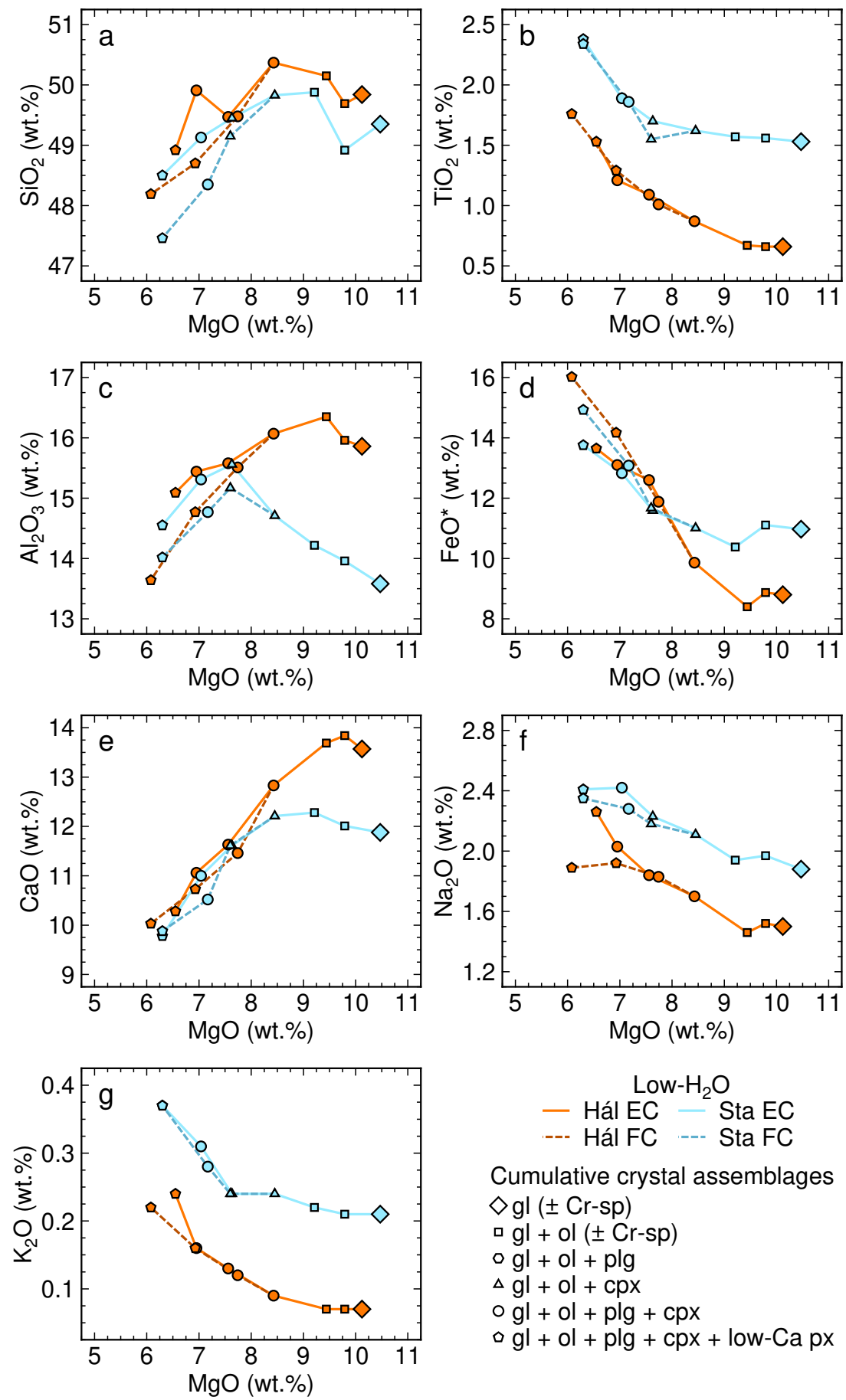

Cumulative crystal assemblages

$\diamond \mathrm{gl}( \pm \mathrm{Cr}-\mathrm{sp})$

a gl + ol $( \pm$ Cr-sp)

$\circ \mathrm{gl}+\mathrm{ol}+\mathrm{plg}$

$\Delta \mathrm{gl}+\mathrm{ol}+\mathrm{cpx}$

$\circ \mathrm{gl}+\mathrm{ol}+\mathrm{plg}+\mathrm{cpx}$

$\circ g l+o l+p l g+c p x+$ low-Ca px

Figure A.3: The evolution of glass major element contents in low- $\mathrm{H}_{2} \mathrm{O}$ experiments. Equilibrium (EC) and near-fractional (FC) crystallisation experiments carried out under low- $\mathrm{H}_{2} \mathrm{O}$ conditions. Data are shown for both depleted Háleyjabunga (Hál) and enriched Stapafell (Sta) analogues. Symbols show phase assemblages: gl, glass; Cr-sp, Cr-spinel; ol, olivine; cpx, clinopyroxene; plg, plagioclase; low-Ca px, low-Ca pyroxene. 

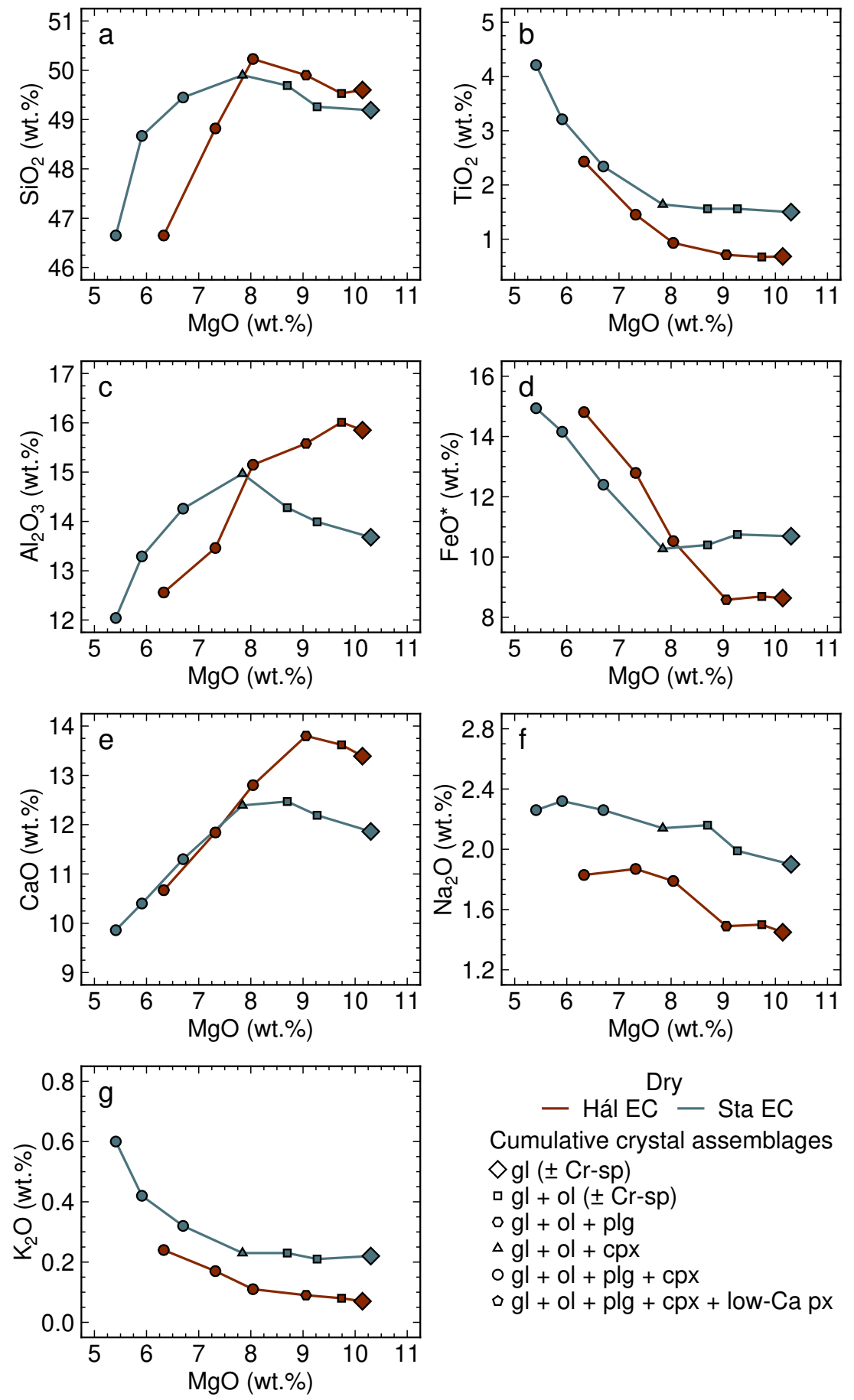

Cumulative crystal assemblages

$\diamond \mathrm{gl}( \pm \mathrm{Cr}-\mathrm{sp})$

a gl + ol ( \pm Cr-sp)

o $\mathrm{gl}+\mathrm{ol}+\mathrm{plg}$

$\Delta \mathrm{gl}+\mathrm{Ol}+\mathrm{cpx}$

$\circ \mathrm{gl}+\mathrm{ol}+\mathrm{plg}+\mathrm{cpx}$

$\checkmark \mathrm{gl}+\mathrm{ol}+\mathrm{plg}+\mathrm{cpx}+\mathrm{low}-\mathrm{Ca} \mathrm{px}$

Figure A.4: The evolution of glass major element contents in nominally dry experiments. Equilibrium crystallisation (EC) experiments carried out under nominally dry conditions. Data are shown for both depleted Háleyjabunga (Hál) and enriched Stapafell (Sta) analogues. Symbols show phase assemblages: gl, glass; Cr-sp, Cr-spinel; ol, olivine; cpx, clinopyroxene; plg, plagioclase; low-Ca px, low-Ca pyroxene. 

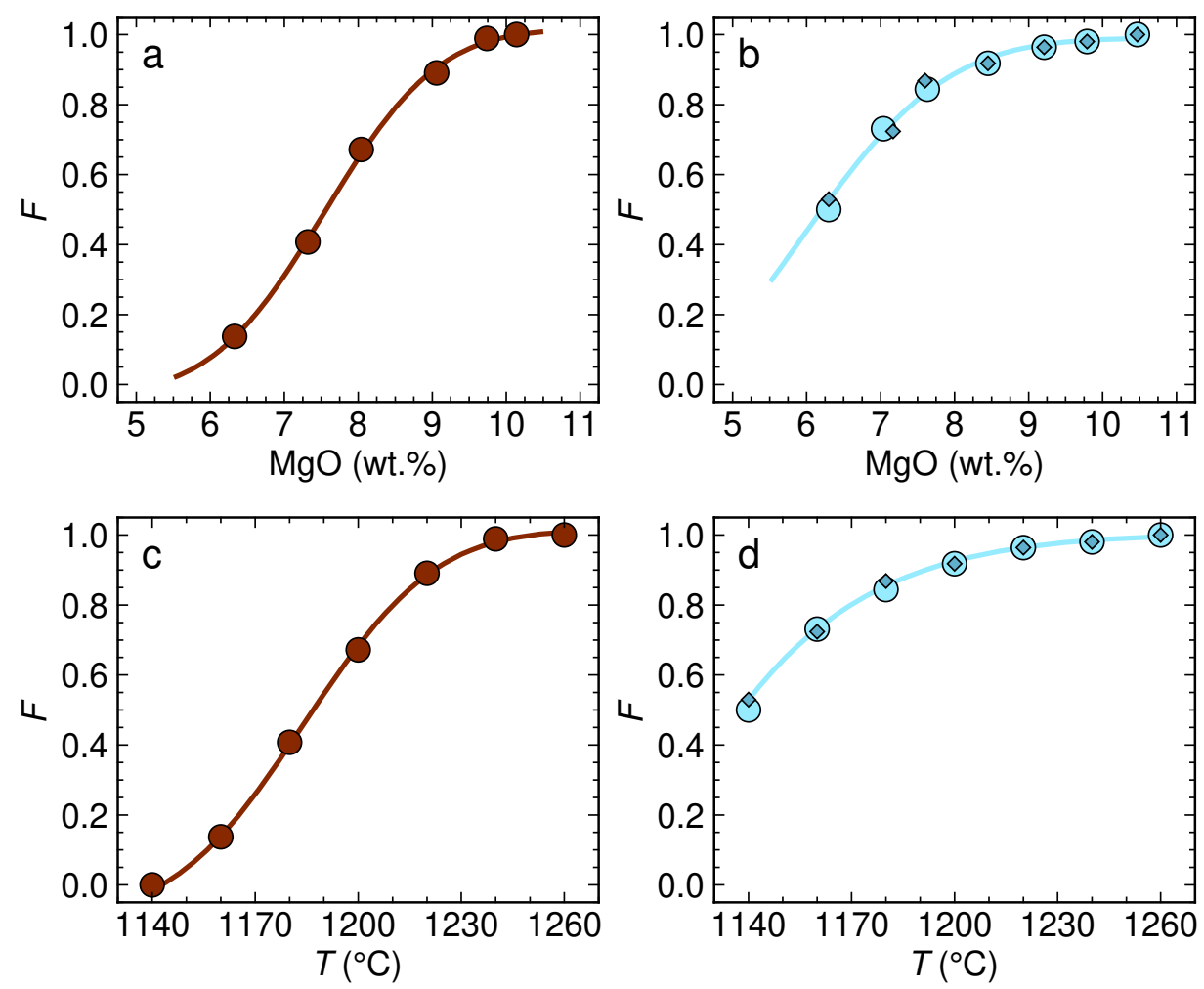

O Hál EC dry

— Hál exp param

O Sta EC low- $\mathrm{H}_{2} \mathrm{O}$

$\diamond$ Sta FC low- $\mathrm{H}_{2} \mathrm{O}$

Figure A.5: Plots showing the error-function fitting used to parametrise the evolution of $F$ as functions of (a and b) melt $\mathrm{MgO}$ content and (c and d) $T \cdot \mathrm{MgO}-F$ and $T-F$ relationships were parametrised using nominally dry experiments on the depleted Háleyjabunga (Hál) analogue and low- $\mathrm{H}_{2} \mathrm{O}$ experiments on the enriched Stapafell (Sta) analogue because these most closely reflect the natural variability in Icelandic end-member systems. Maximum uncertainties in $F$ estimated from the summed residuals of mass balance calculations are no greater than the symbols used. 

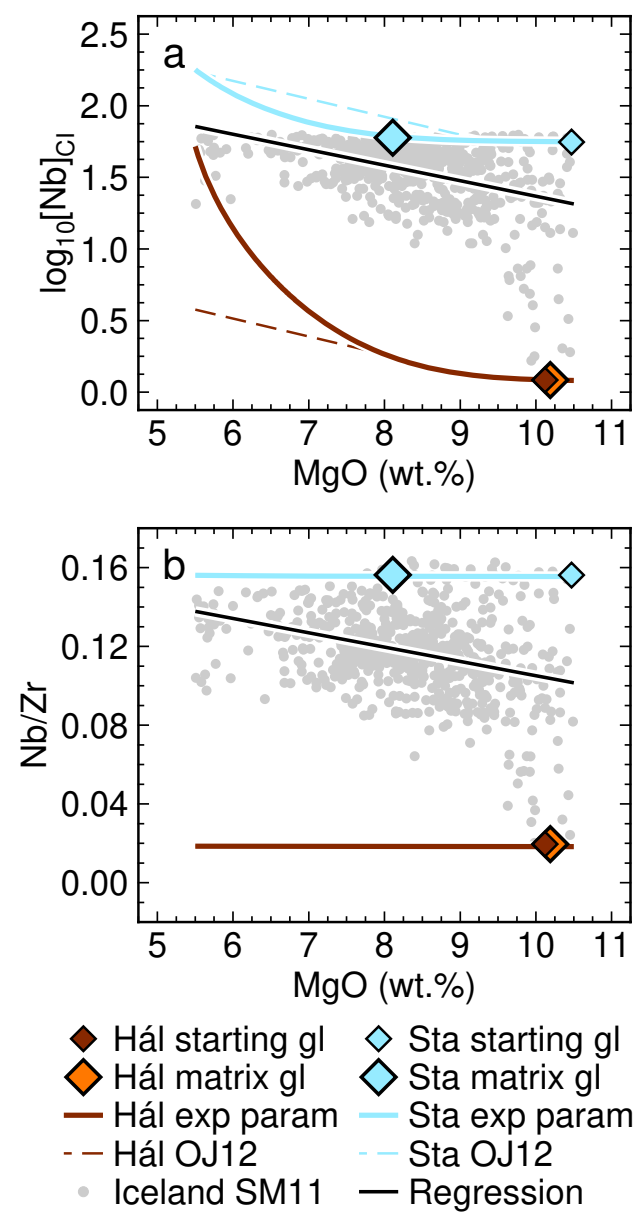

Figure A.6: Comparing ITE evolution trends predicted using our experimental findings with natural data from Iceland. (a) Log-linear plots of $\mathrm{MgO}-\mathrm{Nb}$ systematics of glass and whole-rock samples from southwest Iceland plotted (Shorttle and Maclennan, 2011) (SM11). A regression through the natural data is shown with a solid black line. The compositions of end-member Icelandic matrix glasses and synthetic analogues are shown as large and small coloured diamonds respectively. Solid lines show the evolution of melt La contents predicted from the Rayleigh fractionation equation using a constant partition coefficient from O'Neill and Jenner (2012) (OJ12) and end-member-specific $\mathrm{MgO}-F$ relationships parametrised using our experiments on depleted Háleyjabunga and enriched Stapafell analogues under dry and low- $\mathrm{H}_{2} \mathrm{O}$ conditions respectively. Dashed lines show equivalent predictions made using the $\mathrm{MgO}-F$ relationship given by O'Neill and Jenner (2012). (b) $\mathrm{MgO}-\mathrm{Nb} / \mathrm{Zr}$ systematics of glass and whole-rock samples from southwest Iceland with the results of calculations equivalent to those shown in (a). 

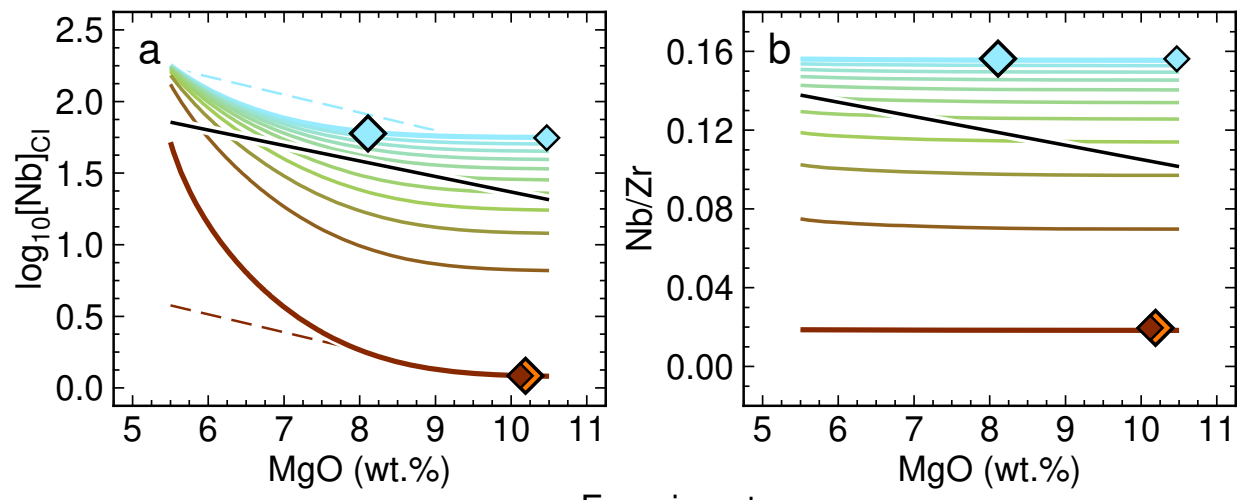

Hál starting gl $\diamond$ Sta starting gl

$\diamond$ Hál matrix gl $\diamond$ Sta matrix gl

- Hál exp param

- - Hál OJ12

Sta exp param

- Regression

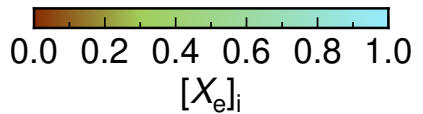

Sta OJ12

$$
\left[X_{\mathrm{e}}\right]_{\mathrm{i}}
$$

Figure A.7: Plots showing how melt (a) $\mathrm{Nb}$ and (b) $\mathrm{Nb} / \mathrm{Zr}$ evolve as functions of $\left[X_{\mathrm{e}}\right]_{\mathrm{i}}$ and $\mathrm{MgO}$. Melt evolution trajectories were calculated using the same methods as those to construct Fig. A.7. End-member compositions, regressions through natural data and melt evolution trajectories predicted using the $\mathrm{MgO}-F$ relationship given by O'Neill and Jenner (2012) (OJ12) are reproduced from Fig. A.7 for context. 

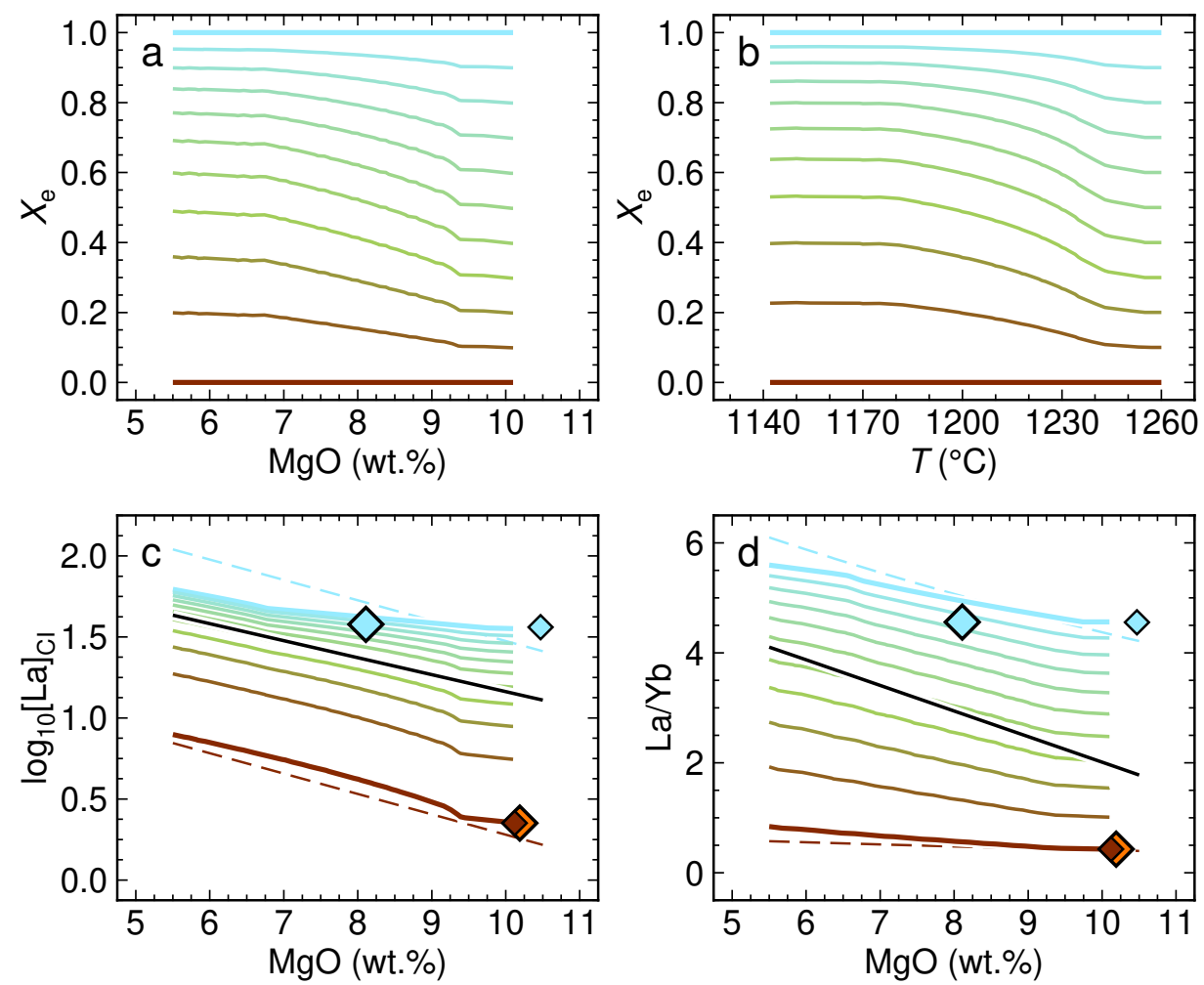

MELTS

Hál starting gl

$\checkmark$ Hál matrix gl

- Hál OJ12

Sta starting gl

Sta matrix gl

- Regression SM11

Sta OJ12

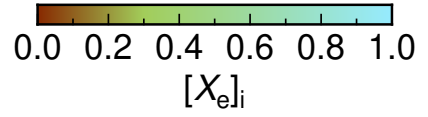

Figure A.8: Plots showing melt evolution trends equivalent to those presented in Fig 8 but derived from calculations with the MELTS algorithm instead of parametrised experimental data. These plots demonstrate that MELTS simulations capture the first-order signals present in our experimental dataset and can thus be used to extend our approach to systems beyond Iceland, even if absolute differences between end-member systems are underestimated. 